OPEN ACCESS

Edited by:

Bin Tang,

Hangzhou Normal University, China

Reviewed by:

Michael A. Menze,

University of Louisville, United States

Takahiro Kikawada,

National Agriculture and Food

Research Organization (NARO), Japan

*Correspondence: Jonathan D. Hibshman hibsjo01@email.unc.edu

Specialty section:

This article was submitted to Invertebrate Physiology, a section of the journal

Frontiers in Physiology

Received: 06 August 2020

Accepted: 25 September 2020

Published: 23 October 2020

Citation:

Hibshman JD, Clegg JS and Goldstein B (2020) Mechanisms of Desiccation Tolerance: Themes and Variations in Brine Shrimp,

Roundworms, and Tardigrades.

Front. Physiol. 11:592016.

doi: 10.3389/fphys.2020.592016

\section{Mechanisms of Desiccation Tolerance: Themes and Variations in Brine Shrimp, Roundworms, and Tardigrades}

\author{
Jonathan D. Hibshman ${ }^{1 *}$, James S. Clegg ${ }^{2}$ and Bob Goldstein ${ }^{1,3}$ \\ ${ }^{1}$ Department of Biology, The University of North Carolina at Chapel Hill, Chapel Hill, NC, United States, ${ }^{2}$ Bodega Marine \\ Laboratory, University of California, Davis, Davis, CA, United States, ${ }^{3}$ Lineberger Comprehensive Cancer Center, \\ The University of North Carolina at Chapel Hill, Chapel Hill, NC, United States
}

Water is critical for the survival of most cells and organisms. Remarkably, a small number of multicellular animals are able to survive nearly complete drying. The phenomenon of anhydrobiosis, or life without water, has been of interest to researchers for over 300 years. In this review we discuss advances in our understanding of protectants and mechanisms of desiccation tolerance that have emerged from research in three anhydrobiotic invertebrates: brine shrimp (Artemia), roundworms (nematodes), and tardigrades (water bears). Discovery of molecular protectants that allow each of these three animals to survive drying diversifies our understanding of desiccation tolerance, and convergent themes suggest mechanisms that may offer a general model for engineering desiccation tolerance in other contexts.

Keywords: desiccation tolerance, anhydrobiosis, Artemia, tardigrade, nematode, C. elegans, trehalose, LEA proteins

\section{INTRODUCTION}

Water is essential for life. The metabolism of life occurs in an aqueous environment, and the biological constituents of cells - DNA, RNA, protein, and membranes - are all unstable during desiccation. However, some animals defy this reasoning, surviving in the near-absence of water by entering a quiescent state and later resuming activity upon rehydration. Antonie van Leeuwenhoek first described reviving dehydrated "animalcules" from the sediment in his gutter in 1702 (Keilin, 1959). Other investigators followed in his footsteps to conduct similar experiments, yet the seemingly miraculous survival and revitalization of desiccated animals remained controversial (Keilin, 1959). The writing of $18^{\text {th }}$ century biologist Lazzaro Spallanzani captures the astonishing nature of this feat of survival:

To affirm that a being, whose animation has been suspended for an immoderate length of time, even for years, can, in virtue of certain conditions, be revived, has so singular and paradoxical an appearance, that reason finds it repugnant to admit the fact. But to produce an animal which has been stiff and motionless, withered, disfigured, and contracted, utterly incapable of any corporeal function. . . and, by a particular treatment, to make it renovate every action that it could perform before; ...not only will it bear perfect conviction to the mind that it has come from a state which, if it was not death, certainly cannot be called life, but that it again lives as completely as before its animation was suspended or destroyed. Some animals in the world enjoy this wonderful prerogative (Translated from original Italian in Spallanzani and Dalyell, 1803). 
The suspended state between life and death that Spallanzani describes is now known as anhydrobiosis, or "life without water." Some organisms, like the African killifish whose embryos can survive evaporation of ephemeral pools, prevent water loss by insulating cells with cuticle or other barriers that serve to trap water inside (Podrabsky et al., 2001). These are considered to be desiccation resistant organisms. However, certain multicellular animals are able to survive even in the absence of almost all intracellular water. These are true anhydrobiotes. So far, anhydrobiotic survival has been observed in tardigrades, roundworms, rotifers, and select arthropods including brine shrimp and chironomid midges. Upon dehydration, these animals significantly reduce metabolic activity and mount a regulated response to produce cellular protectants. Researchers have sought to identify protective mechanisms in many of the known anhydrobiotic organisms, and each organism has revealed new aspects of the biology of desiccation tolerance. Much can be learned by comparing work across these organisms and identifying common themes, and variations on those themes, that allow for the remarkable ability of animals to survive complete desiccation.

This review summarizes major advances in our knowledge of the desiccation responses of three anhydrobiotic animals: brine shrimp (genus Artemia), roundworms (with a focus on Caenorhabditis elegans), and tardigrades. Figure 1 shows examples of each animal in anhydrobiotic and active states. During desiccation, Artemia, roundworms, and tardigrades all undergo substantial physical and physiological changes. Artemia are able to survive dehydration as diapausing embryos (Figure 1A). Dauer larvae of the nematode C. elegans responds to desiccation by curling into a circular shape (Figure 1C). Desiccated tardigrades enter the contracted and shriveled tun state (Figure 1E). We focus on Artemia, C. elegans, and tardigrades because there is some overlap in features of desiccation tolerance between these organisms, and there are also meaningful differences in survival strategies. Importantly, each of these organisms is a true anhydrobiote, surviving in the absence or near absence of intracellular water. Each has been reported to have virtually no water when dried. Artemia have as little as $2 \%$ water relative to the dry weight of cysts, and desiccated C. elegans and tardigrades each retain only $2-3 \%$ of the water that was present in their active states (Crowe, 1972; Clegg, 1974; Clegg and Cavagnaro, 1976; Erkut et al., 2011).

One key distinction between these animals is differences in the timeline of responsiveness to desiccation. Tardigrades and roundworms (nematodes) that are exposed to desiccation conditions are able to survive as larvae or adults, whereas Artemia are only able to survive desiccation as embryonic cysts. The decision to make a desiccation resistant cyst is made in the previous generation rather than by the animal that will itself experience drying. A second difference between these three animals is the correlation between diapause and desiccation tolerance. Diapause is a state of suspended development in response to environmental cues. Artemia cysts enter an embryonic diapause, and C. elegans survive desiccation in dauer diapause (Drinkwater and Crowe, 1987; Erkut et al., 2011).
Tardigrades, on the other hand, enter the quiescent tun state and survive desiccation without an alternative developmental trajectory. Although some species of tardigrades can form diapausing cysts, encystment does not ensure desiccation tolerance (Bertolani et al., 2004). Thus, a comparative organismal approach to desiccation tolerance should nuance our views and allow for identification of both unique and conserved mechanisms of anhydrobiosis.

The approaches researchers have employed in studying Artemia, nematodes, and tardigrades have been somewhat complementary and revealed different aspects of the physiology and molecular details of desiccation resistance. In this review we explore the molecules and mechanisms of desiccation tolerance, highlight common themes, and suggest open questions whose answers will be instrumental to the advancement of our understanding of desiccation tolerance.

\section{ARTEMIA}

Some of the earliest work on desiccation tolerance was carried out on encysted embryos of brine shrimp (genus Artemia). Johannes Albertus Schlosser is credited with the discovery and initial description of Artemia (Sliggers and Engelmann, 2015). Schlosser originally found the "brine worms" in salt water along the coast in Lymington, England in 1755 (see Sliggers and Engelmann, 2015). Artemia are important in aquaculture as food for fish, and they have been marketed as "sea monkeys" as pets for children (Sorgeloos, 1980; Berenbaum, 1999). The commercial uses of Artemia and the related commercial interest in developing culture methods fortuitously facilitated the use of these animals as a laboratory model for the study of diapause and resistance to stresses including anoxia, various forms of radiation, and desiccation (MacRae, 2016). Multiple species of Artemia are able to survive these stresses as diapausing cysts (Hengherr et al., 2011b).

Artemia present an interesting case study of environmental regulation of diapause and stress resistance; they have two alternative developmental trajectories. If environmental conditions are favorable, females retain their developing embryos and release free-swimming nauplius larvae (ovoviviparous development); however, when environmental conditions are poor, females will instead release gastrula-stage embryos (oviparous development) that diapause until conditions amenable to hatching and development are present (see Figures 1A,B) (Sorgeloos, 1973; Drinkwater and Crowe, 1987; Liang and MacRae, 1999; Nambu et al., 2004, 2008). The late gastrula stage embryos arrest development concurrent with a drop in intracellular $\mathrm{pH}$, and are surrounded by a thick, multi-layered, protective shell (Busa et al., 1982; Busa and Crowe, 1983; Liu et al., 2009). These dormant cysts are metabolically inactive and can withstand a variety of insults including anoxia, osmotic stress, temperature extremes, high levels of radiation, and desiccation (Clegg, 1967, 1997, 2005; MacRae, 2016). To date, studies of Artemia desiccation resistance have converged on a few key features that contribute to their desiccation tolerance. 

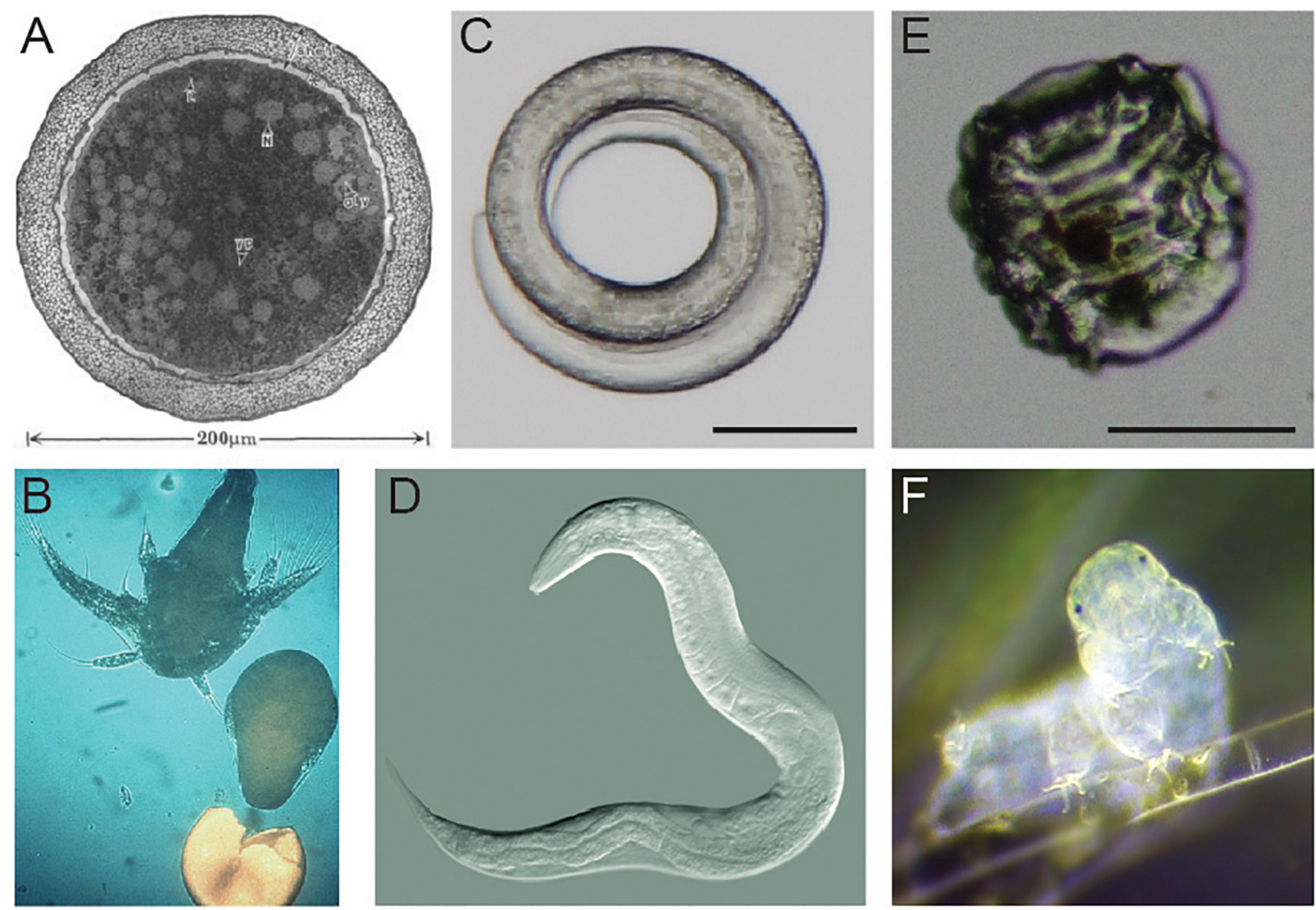

FIGURE 1 | Examples of Artemia, Caenorhabditis elegans, and a tardigrade. (A) A transmission electron micrograph of an encysted embryo of Artemia franciscana. This image is reproduced with permission from Clegg et al., 1999. (B) A nauplius larva of Artemia hatches. Photo credit: Patrick Sorgeloos. (C) A desiccated dauer larva of $C$. elegans in the typical curled form. Scale bar $=50 \mu \mathrm{m}$. Photo credit: J. Hibshman. (D) A reproductive C. elegans adult. Photo credit: B. Goldstein. (E) A tardigrade (Hypsibius exemplaris) in the anhydrobiotic tun state. Scale bar $=50 \mu \mathrm{m}$. Photo credit: J. Hibshman. (F) An active tardigrade (Hypsibius exemplaris). Photo credit: Sinclair Stammers.

\section{Cyst Shell}

The shell of a dormant cyst is the interface between the organism and the environment. Some animals protect against dehydration by retaining water. Artemia cysts are anhydrobiotic, meaning they lose nearly all intracellular water. Thus, the shell of Artemia cysts does not prevent water loss. If the shell does not function to maintain water, how does it contribute to desiccation resistance? The shell slows the rate of water loss from embryos, and by limiting the rate of dehydration, the shell may provide more time for the embryo to mount responses to desiccation such as a gradual slowdown of metabolism and production of protectants required to ultimately survive desiccation (Clegg, 2005).

The shell is synthesized from secreted products of the shell glands of the female, and consists of three layers: an outer cuticle, a middle alveolar layer, and the innermost fibrous layer (Morris and Afzelius, 1967; Anderson et al., 1970; Liu et al., 2009). These layers are porous to water and $\mathrm{CO}_{2}$, but are able to serve as a barrier against many toxins (MacRae, 2016). Perhaps most importantly in the context of desiccation, the shell offers mechanical stability and protection from external damage to the embryos. Depletion of a shell gland-specifically expressed gene (SGEG) compromises the structure of the shell. Upon desiccation or osmotic stress, cysts with these disrupted shells do not maintain a spherical shape, but instead collapse (Liu et al., 2009). Similarly, disruption of the shell by knockdown of SGEG1 or SGEG2 increases sensitivity to UV radiation, freezing, and heat stress (Dai et al., 2011). Other studies have found similar results, with manual decapsulation (removal of the outermost layer of the shell) sensitizing cysts to UV irradiation, heat, and desiccation (Sorgeloos et al., 1977; Tanguay et al., 2004; Clegg, 2005; Liu et al., 2009). The protective ability of cysts' shells therefore extends beyond desiccation and serves as a reminder of the complex environment in which Artemia live and the variety of concurrent stresses they may encounter and survive.

\section{Trehalose Synthesis}

Trehalose is a non-reducing disaccharide of glucose that has been demonstrated to be protective in diverse anhydrobiotes (Crowe, 2002). Although trehalose is not synthesized in vertebrates, it can improve desiccation tolerance when provided to human cells (Guo et al., 2000; Collins and Clegg, 2004; Argüelles, 2014). 
Artemia embryos developing into cysts synthesize trehalose in large quantities of up to around 15\% of the embryo's dry weight, while non-dormant embryos have virtually no measurable trehalose (Clegg, 1965). Trehalose has been implicated as a way to replace water as cells dehydrate, a model known as the water replacement hypothesis (Crowe and Clegg, 1973; Clegg et al., 1982; Crowe, 2002).

\section{Metabolic Adaptations}

Metabolic activity is negligible in dormant cysts; however, in preparation for encystment there are a couple of metabolic changes that occur. Aside from the significant upregulation of trehalose, there is increased production of glycerol and glycogen (Clegg, 1962, 1965). It is possible that glycerol contributes to hatching of cysts, and glycerol has proven effects in freezetolerance (Clegg, 1964). Glycogen also provides a means of osmotic regulation by storing individual molecules of glucose in long branched chains. It remains unclear the extent to which production of glycerol and glycogen might be mechanisms for osmo-regulation and desiccation survival versus an energy store to be utilized during recovery. Trehalose may also be converted to these molecules - possibly contributing to osmo-protective and energetic functions (Clegg, 1964).

\section{Artemin}

Artemin is a ferritin homolog in Artemia and has demonstrated activity as a molecular chaperone (Chen et al., 2007). Artemin is significantly upregulated in dormant cysts and has been reported to comprise $7-13 \%$ of the cyst's total soluble protein (De Graaf et al., 1990; King et al., 2014). By sequence homology, artemin is similar to ferritin, which assembles into a 24-mer structure that functions as a cage that holds iron in its center, acting to regulate iron homeostasis. Artemin similarly oligomerizes as a 24-mer, but does not bind iron. Each monomer contains a tail that protrudes into the center of the barrel such that iron is excluded (Chen et al., 2003, 2007). Despite losing the iron-binding function of ferritin, artemin has been demonstrated to have chaperone activity: it can prevent aggregation of citrate synthase and other proteins in vitro (Chen et al., 2007; Hu et al., 2011; Shahangian et al., 2011). Thus, the massive quantity of artemin produced in dormant cysts likely functions to prevent or reverse desiccation-induced protein aggregation and proteotoxicity via this chaperone function.

\section{Small Heat Shock Proteins}

The protein p26 is a small heat shock protein, with a characteristic alpha-crystallin domain flanked by disordered N-terminal and C-terminal regions (Liang et al., 1997a,b; Laksanalamai and Robb, 2004). p26 is transcriptionally upregulated during cyst formation, and expression levels decline rapidly upon rehydration and larval development (Liang and MacRae, 1999). Normally, environmental cues like low temperature exposure or changes in salinity are required for embryos to exit diapause and resume development (Drinkwater and Crowe, 1987). Knockdown of p26 by RNAi before diapause entry results in spontaneous exit from diapause, and reduces the hatching rate of cysts exposed to freezing and desiccation, as well as heat shock (King and MacRae, 2012). p26 can also confer resistance to oxidative stress and desiccation when expressed in heterologous systems (Collins and Clegg, 2004; Ma et al., 2005). Other small heat shock proteins were subsequently discovered in Artemia. Hsp21 and Hsp22 are both upregulated in cysts and have demonstrable chaperone activity (Qiu and MacRae, 2008a,b). Cysts express p26 at much higher levels than Hsp21 and Hsp22, and Hsp21 and Hsp22 are seemingly less important for survival of stress than is p26 (King et al., 2013).

Although small heat shock proteins are typically only 15$42 \mathrm{kDa}$, they often oligomerize to form larger complexes (Kim et al., 1998; Haslbeck, 2002). Likewise, p26, although only $20.8 \mathrm{kDa}$ as a monomer, forms higher order complexes. It was reported that in vivo p26 oligomerizes into complexes of around 27 monomers - over $700 \mathrm{kDa}$ (Liang et al., 1997a). Analysis of p26 heterologously expressed in bacteria or cultured mammalian cells confirms oligomerization, albeit to a lesser extent, with the most common oligomers containing 5 monomers (Sun et al., 2004). Assembly into higher order oligomers was shown to depend on the N-terminal tail of the protein (Sun et al., 2004). Other targeted mutations within the alpha-crystallin domain can also disrupt oligomerization, suggesting a role for the crystallin domain in the oligomerization interface (Sun et al., 2006).

Small heat shock proteins can localize in different parts of cells. p26 has been detected in both the cytoplasm and the nucleus. Antibody staining revealed formation of distinct p26 foci within the nucleus (Liang et al., 1997a; Willsie and Clegg, 2001). The nucleus may be the predominant site of action as the protein is trafficked from the cytoplasm to the nucleus during diapause and in response to anoxia, $\mathrm{pH}$, or temperature changes (Clegg et al., 1995; Jackson and Clegg, 1996; Willsie and Clegg, 2001). When p26 is translocated into the nucleus during diapause and stress, it associates with the nuclear matrix, although other localization sites are possible (Willsie and Clegg, 2002).

The activity of small heat shock proteins as chaperones is likely to be non-enzymatic, as they associate with misfolded proteins to prevent further denaturation and aggregation during desiccation stress (Jakob et al., 1993; Chakrabortee et al., 2012). sHSPs have been dubbed holdases by nature of their activity to surround misfolded proteins and prevent aggregation until an ATP-driven heat shock protein like Hsp70 can bind and refold the protein; indeed, p26 and Hsp70 were shown to co-localize in the nucleus (Willsie and Clegg, 2002).

\section{Hsp70}

The $70 \mathrm{kDa}$ heat shock proteins (Hsp70s) are a family of ATPdependent chaperones essential for protein folding. Knockdown of one family member, Hsp70, in Artemia sensitizes developing nauplii to heat stress and infection with the bacterium Vibrio campbellii (Iryani et al., 2017; Junprung et al., 2019). Knockdown of Hsp70 has a modest effect on survival of desiccated and frozen cysts (Iryani et al., 2020). J-domain proteins are a prominent family of co-chaperones that assist Hsp70 with protein folding and can confer client specificity (Kampinga and Craig, 2010). Two J-domain proteins have been identified in Artemia: ArHsp40 and ArHsp40-2 (Jiang et al., 2016; Rowarth and MacRae, 2018b). Knockdown of either of the genes encoding these proteins reduces the percentage of cysts that are able to 
hatch following freezing and desiccation (Rowarth and MacRae, 2018a). Developmentally, ArHsp40 and ArHsp40-2 reach their peak expression levels in embryos exiting diapause (Jiang et al., 2016; Rowarth and MacRae, 2018b). This timeline is consistent with p26 preventing protein misfolding and aggregation during desiccation, and with Hsp70 acting in concert with ArHsp40 and ArHsp40-2 during early stages of recovery to refold proteins.

\section{LEA Proteins}

Synthesis of intrinsically disordered proteins (IDPs) is a common mechanism contributing to anhydrobiosis in a variety of organisms. One of the most prominent examples of an IDP is the family of late embryogenesis abudant (LEA) proteins. LEA proteins were originally identified in plants, but subsequently have been found in multiple animal species, including Artemia (Dure et al., 1981; Baker et al., 1988; Browne et al., 2002; Hand et al., 2006; Warner et al., 2010, 2012; Hatanaka et al., 2013). There are seven classes of LEA proteins that have been defined in plants, but most animals have only group 3 LEA proteins (Battaglia et al., 2008). Artemia contain LEA proteins representing groups 1,3 , and 6 , making them apparently unique to date among animals (Wu et al., 2011; Janis et al., 2017). These LEA proteins and the mRNAs encoding them are enriched in diapausing cysts (Hand et al., 2006; Sharon et al., 2009; Warner et al., 2010, 2012; Boswell et al., 2014b).

Significant upregulation of LEAs in diapause-destined Artemia embryos suggests a possible function in desiccation resistance. A common experimental strategy to test for LEA function has been to assess chaperone activity or protective capacity in heterologous or in vitro contexts. LEA proteins from Artemia are capable of protecting liposomes, stabilizing membranes, attenuating protein aggregation, and conferring resistance to osmotic and desiccation stresses (Sharon et al., 2009; Li et al., 2012; Marunde et al., 2013; Hand and Menze, 2015; Moore and Hand, 2016; Moore et al., 2016; Czernik et al., 2020). While such studies highlight potential functions of LEA proteins, the endogenous roles of these proteins in Artemia have been less well-studied. One study using RNAi knockdown revealed that a group 1 LEA protein is also necessary for desiccation tolerance in Artemia cysts (Toxopeus et al., 2014).

One of the potentially major challenges facing animals undergoing desiccation is the number and diversity of subcellular components that must be protected. The study of Artemia LEA proteins provides insight into the importance of subcellular compartmentalization of the desiccation response. AfrLea3m was the first LEA from an animal that was shown to localize to mitochondria, when bioinformatic predictions of subcellular localization were confirmed with heterologous expression and studies in human cell culture (Menze et al., 2009). Ensuing subcellular fractionation experiments identified different LEA proteins in cytosolic, mitochondrial, and nuclear fractions (Warner et al., 2012). Visualizing endogenous LEA proteins with immunofluorescence confirmed the mitochondrial localization of AfrLEA3m and revealed that AfrLEA2 has a primarily cytoplasmic localization, with some faint nuclear localization (Boswell and Hand, 2014). The distribution of different LEA proteins to different parts of a cell may explain the diversity of LEAs that are expressed and could represent a strategy for targeted protection of subcellular compartments. For example, the mitochondrial localization of AfrLEA3m suggests a role in preservation of mitochondria during stress, protecting the integrity of the organelle to provide energy for mounting a desiccation response and to fuel recovery of the cell when rehydrated.

\section{Regulation of Desiccation Resistance}

Desiccation tolerance mechanisms must be coordinated in order to ensure that each cell of a cyst has the required suite of protectants. Many stress responses are under a coherent program of transcriptional regulation (Vihervaara et al., 2018). Identification of "master regulators" of the protectants required for desiccation tolerance suggests that the desiccation response is also subject to coordinated control and could inform the search for additional, novel protectants also controlled by these regulators. In Artemia, the heat shock factor 1 (Hsf1) regulates expression of Artemin and the small heat shock proteins p26, Hsp21, and Hsp22 (Tan and MacRae, 2018, 2019). RNAi knockdown of Hsf1 reduces viability of cysts and sensitizes them to stress, including desiccation (Tan and MacRae, 2018). Hsf1 is one transcription factor that can serve as a regulator of the desiccation response, but there are likely other regulators (transcriptional and post-transcriptional) that are involved. It is further possible that transcriptional co-activators like $p 8$ may provide specificity to the transcriptional initiation of diapause and desiccation resistance (Qiu and MacRae, 2007; Qiu et al., 2007; Lin et al., 2016).

\section{Lessons From Artemia}

The unique life cycle of Artemia has allowed for its use as a model in the study of desiccation tolerance and other forms of stress tolerance. The ability to reproducibly generate diapausing cysts in the lab has offered a window to study mechanisms of both diapause and resistance to extremes. While this system has been valuable for answering both of these questions, some ambiguity remains between adaptations of cysts that are necessary for initiating or maintaining diapause versus those that are involved in desiccation tolerance per se. The overlapping nature of diapause and desiccation resistance likely reflects the ecological contexts in which such stress responses have evolved. Tolerance of high saline environments has likely facilitated co-adaptation to desiccation stress. Although it is unclear what the initial selective pressure was that drove the evolution of encystment - desiccation resistance or high salt - the unique adaptations of Artemia likely reflect the complexity of the natural environment.

The earliest studies of Artemia focused on metabolic adaptations and proteins that were upregulated during initiation of diapause. The identification of trehalose as a prominent metabolite produced in cysts would become an important theme amongst desiccation tolerant organisms. In fact, it has been commonplace to ask early on in the study of any new anhydrobiote the extent to which its tolerance depends on trehalose. Further study of trehalose has also led to theories and mechanisms of desiccation tolerance including the water replacement hypothesis and the cellular vitrification model, both 
of which will be discussed in more detail below (Clegg et al., 1982; Green and Angell, 1989). The early focus on metabolic studies has given way to a more protein-centric approach amongst Artemia researchers. This focus has promoted discoveries like assembly of p26 into oligomers and the structural nature of artemin (Sun et al., 2004; Hu et al., 2011). Evidence for endogenous function of protectants is scarce (see Table 1), as the more common approach has been to analyze protective capacity in vitro or in heterologous systems.

Many questions remain about the protection of cells of the Artemia embryo. For example, encysted embryos are able to develop into pre-nauplii without cell or nuclear divisions (Clegg, 1966; Olson and Clegg, 1978). Therefore, it would appear that the internal components of the nuclei, most notably the DNA, would have to be protected. It is also possible that a period of development without DNA replication allows time for DNA repair (McLennan, 2009). This unique biology of Artemia embryos remains a topic for future research. The discoveries made from studying mechanisms of desiccation resistance in Artemia have synergized with studies in nematodes, the animals to which we now turn our attention.

\section{NEMATODES}

Nematodes were first reported to survive desiccation in the $1700 \mathrm{~s}$ (Needham, 1743). John Needham described adding water to a blighted grain of wheat and seeing fiber-like worms come to life:

...to my great surprise, these imaginary fibers, as it were, instantly separated from each other, took life, moved irregularly, not with a progressive, but twilling motion, and continued so to do for the space of nine or ten hours... (Needham, 1743)

Since Needham's discovery of the reanimation of "fibers," later to be identified as larvae of the plant pathogenic nematode Anguina tritici, desiccation tolerance has been described in numerous species of nematodes, including Aphelenchus avenae, Plectus murrayi, Panagrolaimus superbus, Ditylenchus dipsaci, and C. elegans (Keilin, 1959; Madin and Crowe, 1975; Wharton, 1996; Perry, 1999; Shannon et al., 2005; Adhikari et al., 2009; Erkut et al., 2011; Tyson et al., 2012). For some of these worms, like A. avenae and C. elegans, intracellular water content has been specifically measured, showing depletion to anhydrobiotic levels with loss of nearly all intracellular water (Crowe et al., 1977; Erkut et al., 2011). Although many nematodes have been studied in the context of desiccation resistance, we focus here on C. elegans and supplement that analysis with other species in some instances.

Caenorhabditis elegans is a common model organism with well-developed methods and resources for genetics, cell biology, and imaging that can be used to understand the physiology of stress responses (Brenner, 1974). Of the anhydrobiotic metazoans, C. elegans offers the most resourced molecular toolkit (Wharton, 2011; Dickinson et al., 2013; Erkut and Kurzchalia, 2015; Nance and Frøkjær-Jensen, 2019). Although other nematodes like $A$. avenae have been long appreciated as having anhydrobiotic abilities, it was only relatively recently that $C$. elegans was shown to be a true anhydrobiote, surviving desiccation after losing more than $98 \%$ of their body water content (Madin and Crowe, 1975; Erkut et al., 2011). Some nematodes can withstand desiccation at multiple life stages, but C. elegans is only resistant to desiccation when in the dauer state, a specialized stress-resistant alternative larval stage in which the worms stop feeding (Cassada and Russell, 1975; Erkut et al., 2011). Similar to the diapause of Artemia cysts, C. elegans enter dauer diapause in response to deteriorating environmental conditions by undergoing metabolic and morphological changes including synthesis of a specialized cuticle, radial constriction, and formation of a plug over the mouth (Riddle et al., 1981; $\mathrm{Hu}, 2007)$.

Caenorhabditis elegans has been a productive model for identifying genes involved in anhydrobiosis. Studies have mostly taken two approaches: (1) expression profiling to identify genes whose mRNA abundances change during desiccation and (2) disruption of candidate genes' functions to identify genes that are required for desiccation tolerance. These approaches have identified molecules that suggest a striking diversity of physiological adaptations to desiccation, some prominent examples of which we discuss in the sections below.

\section{Trehalose Synthesis}

Trehalose accumulates in several anhydrobiotic nematode species (Madin and Crowe, 1975; Loomis et al., 1980; Behm, 1997; Shannon et al., 2005). In C. elegans, the upregulation of trehalose synthesis during gradual drying is essential for worms to survive desiccation (Erkut et al., 2011). C. elegans trehalose synthesis is a two-step process that generates trehalose from glucose and UDPglucose, involving trehalose 6-phosphate synthase genes ( $t p s-1$ and $t p s-2)$ and the subsequent dephosphorylation of trehalose 6phosphate by a protein encoded by gob-1 (Kormish and McGhee, 2005). Deletion of both tps genes limits the ability of C. elegans to synthesize trehalose and retain appropriate membrane lipid packaging, and to survive desiccation (Erkut et al., 2011; Abusharkh et al., 2014). Trehalose also functions in other contexts including aging and starvation resistance, suggesting that its protective role may extend beyond desiccation tolerance (Honda et al., 2010; Hibshman et al., 2017; Seo et al., 2018).

\section{Metabolic Adaptations}

During anhydrobiosis, metabolism grinds to an apparent halt (Crowe et al., 1977). However, during gradual desiccation there are a number of preparatory metabolic adaptations that occur. Entry into the dauer state drives restructuring of metabolic flux (O’Riordan and Burnell, 1989, 1990; Burnell et al., 2005). One of the most significant metabolic changes with a demonstrated effect on desiccation tolerance is an upregulation of the glyoxylate shunt (Madin et al., 1985; Erkut et al., 2016). The glyoxylate shunt, involving isocitrate lyase and malate synthase enzymes, is an alternative to the TCA cycle that converts isocitrate to succinate and malate (Braeckman et al., 2009). In C. elegans, isocitrate lyase and malate synthase enzyme activities are performed by a single protein, ICL-1, that carries out both of these functions (Liu et al., 1995). Depletion of icl-1 by RNAi sensitizes C. elegans to desiccation (Erkut et al., 2016). The malate produced 
TABLE 1 | Comparison of molecular strategies for desiccation survival between Artemia, C. elegans, and tardigrades. Genes or proteins implicated in desiccation tolerance are shown.

\begin{tabular}{|c|c|c|c|}
\hline & Artemia & C. elegans & Tardigrades \\
\hline Mechanical stabilization & Cyst shell & Cuticle & Cuticle \\
\hline Metabolic changes & $\begin{array}{l}\text { Production of } \\
\text { glycerol and } \\
\text { glycogen }\end{array}$ & Glyoxylate shunt (icl-1) & \\
\hline Trehalose & Yes & Yes (tps-1, tps-2) & Variable \\
\hline LEA proteins & Groups 1,3,6 & Group 3 (lea-1, dur-1) & Group 3 \\
\hline Heat shock proteins & $\begin{array}{l}\text { Hsp70, J-domain } \\
\text { proteins (ArHsp40, } \\
\text { ArHsp40-2) }\end{array}$ & hsp-70 & Hsp70 \\
\hline Small heat shock proteins (sHSPs) & p26, Hsp21, Hsp22 & F08H9.3, F08H9.4, hsp-12.6 & Hsp27, Hsp30c \\
\hline \multirow[t]{3}{*}{ Oxidative stress response } & & Superoxide dismutase (sod-1) & $\begin{array}{l}\text { Increased superoxide } \\
\text { dismutase activity }\end{array}$ \\
\hline & & $\begin{array}{l}\text { Glutathione peroxidase }(g p x-2, g p x-6 \text {, } \\
g p x-7)\end{array}$ & $\begin{array}{l}\text { Increased peroxidase } \\
\text { activity }\end{array}$ \\
\hline & & Catalase (ctl-1) & \\
\hline Fatty acid desaturation & & $\begin{array}{l}\Delta 6 \text { desaturase } \\
(\text { fat }-3) \\
\Delta 5 \text { desaturase } \\
(\text { fat }-4) \\
\Delta 9 \text { desaturase } \\
\text { (fat-5, fat }-6, \text { fat }-7)\end{array}$ & \\
\hline Polyamine synthesis & & $\begin{array}{l}\text { Ornithine decarboxylase (odc-1) } \\
\text { Spermidine synthase (spds-1) }\end{array}$ & \\
\hline Xenobiotic detoxification & & $\begin{array}{l}\text { Cadmium responsive (cdr-2, cdr-3) } \\
\text { Glyoxylase III (djr-1.1, djr-1.2) }\end{array}$ & \\
\hline Others & $\begin{array}{l}\text { Artemin (Ferritin) } \\
\text { Heat shock factor } 1 \\
\text { (Hsf1) }\end{array}$ & $\begin{array}{l}\text { Calexcitins (cex-1, cex-2) } \\
\text { Trypsin like protease }(\boldsymbol{t r y}-\mathbf{5}) \\
\text { UDP-Glucuronosyltransferase (ugt-1) } \\
\text { Serine threonine kinase (C04G2.2) } \\
\text { TRP channel (osm-9) } \\
\text { Notch ligand (osm-11) } \\
\text { Patched related protein (daf-6) }\end{array}$ & $\begin{array}{l}\text { Tardigrade-specific } \\
\text { disordered proteins (CAHS, } \\
\text { SAHS, MAHS) }\end{array}$ \\
\hline
\end{tabular}

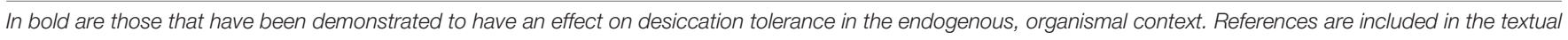
descriptions for each item delineated in the table. Genes included from C. elegans without specific textual references are described in Erkut et al. (2013).

from glyoxylate shunt activity provides an energetic input for gluconeogenesis and ultimately the synthesis of trehalose during preconditioning for desiccation (Figure 2) (Erkut et al., 2016). Thus, it is likely that metabolic adaptations such as upregulation of the glyoxylate shunt primarily function to fuel production of downstream protectants, rather than having an intrinsic protective ability. In short, the glyoxylate shunt promotes the conversion of fatty acids into carbohydrates like trehalose that can function as protectants.

\section{LEA Proteins}

The first report of an animal LEA protein was in the nematode Aphelenchus avenae, where it was shown to be upregulated in response to desiccation (Browne et al., 2002, 2004). C. elegans contains two group 3 LEA protein-encoding genes, lea-1, and dur-1 (dauer unp-regulated) (Browne et al., 2004; Gal et al., 2004; Erkut et al., 2013). Each of these genes' expression is induced by desiccation, and knockdown reduces the ability of worms to survive desiccation (Gal et al., 2004; Erkut et al., 2013). The initial discovery of an LEA protein in $A$. avenae was followed by a flurry of papers reporting LEA proteins in a wide variety of animals (including Artemia, as already discussed) (Gal et al., 2004, 2006; Tunnacliffe et al., 2005; Hand et al., 2006; Kikawada et al., 2006). Despite identification of many animal LEAs, most studies of these proteins in the organismal context are limited to expression profiling and rare cases of functional validation by knockdown. Like Artemia LEA proteins, nematode LEA proteins have also been studied through heterologous expression or in vitro studies. An LEA protein from A. avenae can prevent protein aggregation in multiple contexts, and can modestly improve osmotolerance of human cells (Goyal et al., 2005; Chakrabortee et al., 2007; Liu et al., 2011). LEA-1 from C. elegans can also reduce aggregation of proteins and can 


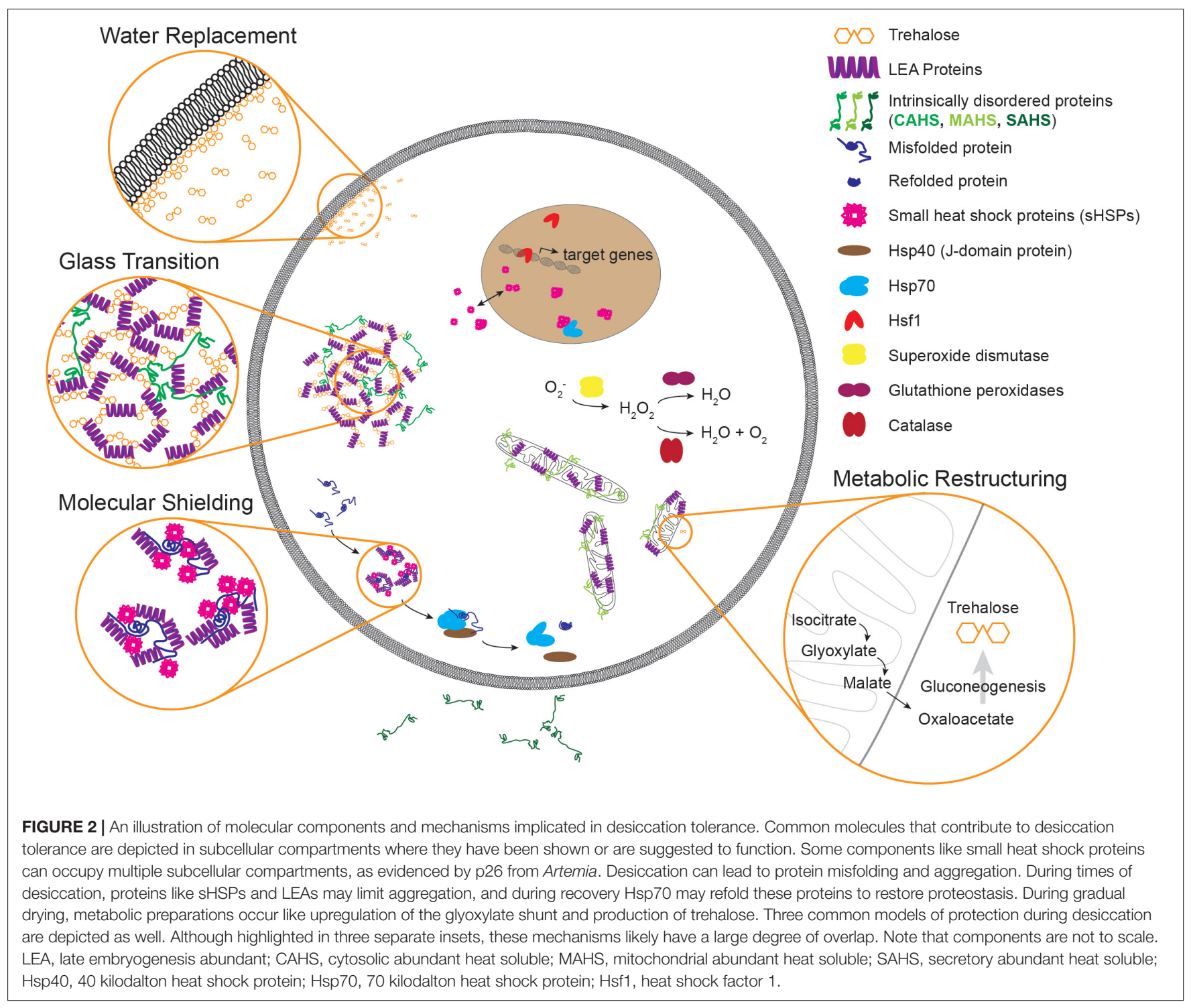

improve bacterial resistance to oxidative stress and desiccation (Liu et al., 2019).

Late embryogenesis abudant proteins are highly hydrophilic and intrinsically disordered in solution, confounding traditional intuition that proteins must fold into functional forms (Tunnacliffe and Wise, 2007). However, the structure of LEA proteins is highly responsive to conditions within the cell. Using the LEA1 protein from the nematode Aphelenchus avenae as a model, Goyal et al. (2003) demonstrated an increase in secondary structure during desiccation. Specifically, LEA proteins fold into amphipathic alpha helices in the absence of water. This has also been shown for C. elegans LEA-1 (Liu et al., 2019). Folding into alpha helices during desiccation (or similar experimentally simulated conditions) has proven to be a common attribute of a variety of LEA proteins and model peptides from animals including nematodes and Artemia (Tolleter et al., 2007; Li and He, 2009; Boswell et al., 2014a; Hand and Menze, 2015; LeBlanc et al., 2019). Amphipathic alpha helices are thought to stabilize molecular interactions by maintaining appropriate charge contact sites via opposite charged and non-polar faces of the helix (Giménez-Andrés et al., 2018). LEA proteins may also act as an interface between air and water to prevent protein aggregation (Yuen et al., 2019). The amphipathic structure of LEA proteins allows for diverse functions. LEA proteins act as "molecular shields" by limiting aggregation of misfolded proteins, contribute to membrane stabilization, and are constituents of biological glasses as dehydrating cells vitrify (Hand et al., 2011).

\section{Heat Shock Proteins}

In a microarray study measuring transcriptional changes during desiccation, the small heat shock protein-encoding gene F08H9.4 was the most upregulated gene, increasing mRNA level over 700-fold (Erkut et al., 2013). Two other sHSP-encoding genes, F08H9.3 and hsp-12.6, were also upregulated in response to desiccation. When tested for a function in desiccation survival, 
an $h s p-12.6$ mutant did not affect survival, but mutations in either F08H9.3 or F08H9.4 reduced desiccation tolerance, with F08H9.3 having a more pronounced effect (Erkut et al., 2013). In C. elegans $h s p-70$ is transcriptionally upregulated during desiccation and required for wild-type levels of desiccation tolerance (Erkut et al., 2013). A role for $h s p-70$ in worm desiccation survival highlights again the role of proteostasis in desiccation tolerance.

\section{Oxidative Stress Response}

A common feature of desiccation is oxidative stress (França et al., 2007). Reactive oxygen species (ROS) can accumulate during desiccation, damaging proteins, membranes, and DNA. Multiple nematode species upregulate antioxidant response genes during desiccation (Adhikari et al., 2009; Tyson et al., 2012). For example, in C. elegans the expression levels of several antioxidant genes increase during gradual desiccation, and there is functional evidence that a superoxide dismutase gene (sod-1), several glutathione peroxidases $(g p x-2, g p x-6, g p x-7)$ and catalase (ctl-1) are required for desiccation survival, suggesting that upregulation of these genes (all except $c t l-1$ have increased expression during desiccation) is an adaptive physiological response to gradual desiccation (Erkut et al., 2013).

\section{Fatty Acid Desaturation}

Multiple fatty acid desaturases are transcriptionally upregulated in response to desiccation (Erkut et al., 2013). Additionally, multiple genes involved in fatty acid desaturation are necessary for full desiccation tolerance. These include $\Delta 9$ fatty acid desaturases (fat-5, fat-6, and fat-7), $\Delta 6$ desaturase (fat-3), and $\Delta 5$ desaturase $($ fat -4$)$. Of note, the $\omega 3$ desaturase, fat-1, does not impact desiccation survival, suggesting that arachidonic acid may play a particular role in desiccation resistance (Erkut et al., 2013). How fatty acid desaturation leads to desiccation resistance is an open question. It is possible that breakdown of fatty acids could provide an energy reserve during a time of limited activity of the TCA cycle and oxidative phosphorylation. It is also possible that desaturated fatty acids in lipid bilayers could contribute to membrane fluidity (Crowe et al., 1989). A third possibility is that various lipid species may undergo peroxidation, functioning as sinks for ROS during desiccation.

\section{Regulation of Desiccation Resistance}

Caenorhabditis elegans relies on gradual preconditioning to upregulate the protectants required for desiccation survival (Erkut et al., 2011). Thus, C. elegans (and other multicellular animals) must have mechanisms to recognize gradual loss of water and to induce the responses described above. Even animals like fruit flies that cannot survive total desiccation can sense and respond to humidity (Sayeed and Benzer, 1996). Hygrotaxis, the ability to migrate up or down a humidity gradient, offers a first line of protection from drying as an animal can simply avoid conditions of desiccation. C. elegans exhibits hygrotaxis behavior, a further indication of effective monitoring of humidity (Russell et al., 2014).

Several genes implicated in desiccation resistance suggest an initial outline of some mechanisms involved in hygrosensation.
A mutation in a sensory neuron transient receptor potential (TRP) channel gene, osm-9, limits desiccation survival (Colbert et al., 1997; Erkut et al., 2013). TRP channels in Drosophila antennae regulate hygrosensing, although individual knockdown of osm-9 or any of the other TRP channels in C. elegans does not affect hygrotaxis (Sayeed and Benzer, 1996; Liu et al., 2007; Russell et al., 2014; Enjin et al., 2016). In C. elegans, mechanosensory neurons may detect humiditydependent stretch in the cuticle or epidermis to regulate hygrotaxis (Russell et al., 2014). Additionally, a cGMP gated channel (tax-4) in thermosensory neurons regulates hygrotaxis (Russell et al., 2014). It is somewhat surprising that genes like osm-9 could impact desiccation survival but not hygrotaxis. It is possible that only partially overlapping systems are used for the neuronal regulation of hygrotaxis and the sensing response necessary for desiccation resistance.

Beyond the initial sensing of changes in humidity, this information must be conveyed in some form throughout the organism - likely resulting in altered transcription factor activity and transcriptional regulation of desiccation-related genes. Our understanding of such signaling is sparse, but some clues involve possible roles for a notch ligand (OSM-11), a patched related protein (DAF-6), and mitogen-activated protein kinase (MAPK) signaling (Banton and Tunnacliffe, 2012; Erkut et al., 2013). Specific transcription factors are known to regulate expression of many of the genes and pathways that affect desiccation tolerance. For example, $h s f-1$ regulates the heat shock response and many chaperones, $s k n-1 / \mathrm{Nrf} 2$ is a master regulator of the oxidative stress response, and daf-16/FOXO transcriptionally regulates many genes involved in the glyoxylate shunt and trehalose synthesis during starvation (Hsu et al., 2003; Park et al., 2009; Brunquell et al., 2016; Hibshman et al., 2017). However, there have not yet been any studies specifically testing for a role for some of these well-known transcription factors during desiccation. The tools available in C. elegans make it an ideal animal model system to investigate the spatial and temporal nature of signaling required to mount a desiccation response.

\section{Lessons From Nematodes}

The study of desiccation tolerance in a genetic system has facilitated the discovery of more genes associated with desiccation survival than in Artemia and tardigrades. More genes than discussed above play roles in desiccation tolerance. These genes (from Erkut et al., 2013) are included in Table 1. Although C. elegans studies have unveiled a large number of new molecular players, the mechanisms by which many of these genes contribute to survival remain murky. Further research on C. elegans desiccation resistance should be productive toward continued discovery of protectants and delineation of signaling pathways that contribute to survival, and to better understanding mechanisms used by animals more generally. The molecular mechanisms identified in C. elegans are likely to be conserved among other nematodes, because studies of gene expression find upregulation during desiccation of similar protectants as described above. For example Panagrolaimus superbus increases expression of a small heat shock protein, an 
LEA protein, and several antioxidants in response to desiccation (Tyson et al., 2012).

\section{TARDIGRADES}

Tardigrades, also known as water bears, are microscopic eightlegged invertebrates with the ability to survive a wide range of stresses including radiation, temperature stress, high or low pressure, exposure to space, and desiccation (Seki and Toyoshima, 1998; Goldstein and Blaxter, 2002; Jönsson et al., 2008; Møbjerg et al., 2011; Guidetti et al., 2012; Tsujimoto et al., 2016). Although tardigrades are often championed for tolerance of a broad range of extremes, survival of some of these stresses can rely on prior exposure to desiccation. For example, tardigrades like Ramazzottius varieornatus are only able to survive at high temperatures when they are in the desiccated state (Neves et al., 2020). Thus, the mechanisms of cellular protection that tardigrades engage during desiccation may explain at least in part the tolerance of other extremes.

In order to survive desiccation, most tardigrades contract into a quiescent tun state. Tun formation involves significant structural changes, including a reduction of surface area that may slow the rate of water loss (Wright, 1989; Halberg et al., 2013; Czerneková et al., 2017; Richaud et al., 2020). Nonetheless, tardigrades lose nearly all intracellular water - meeting the criterion for classification as a true anhydrobiote (Crowe, 1972). In anhydrobiosis, oxygen consumption is reduced to near zero, suggesting complete or nearly complete arrest of metabolism (Pigon and Weglarska, 1955). It is worth noting that while the tun form is most commonly associated with desiccation resistance, there are reports of embryos surviving desiccation, as well as some tardigrades in which tun formation is apparently not required for desiccation survival (Guidetti and Jönsson, 2002; Bertolani et al., 2004; Rebecchi et al., 2006; Schill and Fritz, 2008; Hygum et al., 2016).

Recently, there has been an effort to develop tardigrades as a model for the study of the molecular biology of extremes like anhydrobiosis (see Hashimoto and Kunieda, 2017; Goldstein, 2018 for review). As tardigrades have gained in popularity as a research organism, many studies have focused on transcriptional responses to desiccation in various species (Schill et al., 2004; Reuner et al., 2010; Grohme et al., 2011; Wang et al., 2014; Hashimoto et al., 2016; Boothby et al., 2017; Yoshida et al., 2017). In contrast, few studies test for endogenous functions of proteins in tardigrades (Tenlen et al., 2013; Boothby et al., 2017). RNAi for gene knockdown has been demonstrated in a common lab-reared species, Hypsibius exemplaris (recently disambiguated from the closely related species Hypsibius dujardini) (Tenlen et al., 2013; Gasiorek et al., 2018; McNuff, 2018). However, development of further genetic methods and implementation in other species of tardigrades will be instrumental for progress in understanding the endogenous roles of tardigrade proteins.

\section{Varying Dependence on Trehalose}

Despite most known anhydrobiotes producing trehalose as a protective mechanism, not all tardigrades are reliant on trehalose
(Crowe, 2002). Some tardigrades like Adorybiotus coronifer and those of the family Macrobiotidae have been shown to produce trehalose in response to desiccation (Westh and Ramløv, 1991; Hengherr et al., 2008; Jonsson and Persson, 2010). Other species like E. granulatus and E. testudo synthesize low quantities of trehalose but do not upregulate synthesis during desiccation (Hengherr et al., 2008; Jonsson and Persson, 2010). Other tardigrades, like $H$. exemplaris, appear to lack entirely the trehalose 6-phosphate synthase and trehalose 6-P phosphatase enzymes required for trehalose synthesis (Cesari et al., 2012; Boothby et al., 2017; Yoshida et al., 2017). Rotifers are also able to survive desiccation without synthesis of trehalose, suggesting that tardigrades are not unique in this respect (Lapinski and Tunnacliffe, 2003; Tunnacliffe et al., 2005). Even in tardigrades that produce trehalose, the maximum amount reported $(2.9 \%$ of the dry weight in anhydrobiotic Macrobiotus islandicus) is considerably lower than the level of trehalose accumulation reported in Artemia (15\%) or nematodes ( 13\%) (Clegg, 1965; Madin and Crowe, 1975; Crowe et al., 1977; Jonsson and Persson, 2010). The apparent lack of a requirement for trehalose in desiccation tolerance of some tardigrades indicates that other molecules must have protective effects that substitute for the function of trehalose.

\section{Novel Disordered Proteins: MAHS, CAHS, SAHS}

Protectants that function during desiccation must retain their protective properties even during conditions in which most proteins are prone to aggregation and dysfunction. Thus, protective proteins are likely to be resistant to aggregation and retain solubility even during extreme conditions if they are to interact with and preserve other cellular constituents. If protectants that function during desiccation are themselves resistant to severe dehydration stress, this may predispose them to withstand other stresses as well. To identify possible protectant proteins, one approach has been to determine the portion of the proteome that is highly stable and soluble even during stress. The most straightforward method for this has been to search for heat soluble proteins - those that can retain solubility even after transient exposure to near-boiling temperatures. Analysis of the tardigrade proteome has revealed such heat soluble proteins (Yamaguchi et al., 2012).

Tardigrades possess several classes of heat stable proteins: cytosolic abundant heat soluble (CAHS), mitochondrial abundant heat soluble (MAHS), and secretory abundant heat soluble (SAHS) proteins (Yamaguchi et al., 2012; Tanaka et al., 2015). The SAHS proteins have structural similarity to fatty acid binding proteins, but the CAHS proteins do not contain any conserved domains or strong homology to other proteins (Yamaguchi et al., 2012; Fukuda et al., 2017). These proteins are thus likely to be unique to tardigrades, and as a result, they have also been referred to as tardigrade-specific intrinsically disordered proteins (TDPs) (Boothby et al., 2017). Such proteins were first identified from experiments in Ramazzotius varieornatus, and homologs for some of the heat soluble proteins are also present in other tardigrade species including 
H. exemplaris and Milnesium tardigradum (Yamaguchi et al., 2012). Further, some TDPs are transcriptionally upregulated in response to desiccation in $H$. exemplaris and $P$. richtersi (Boothby et al., 2017). Some CAHS proteins show protective effects outside of their normal context in tardigrades: they are sufficient to increase desiccation tolerance of bacteria and yeast, and they can protect an enzyme (lactate dehydrogenase) in solution from desiccation-induced inactivation (Boothby et al., 2017). RNAi knockdown of some CAHS or SAHS proteins reduces desiccation survival in tardigrades (Boothby et al., 2017). These experiments identify extremotolerance protectants that are not only sufficient in heterologous cells or in solution, but that also can be demonstrated to function in vivo.

The potentially broad function of TDPs piques interest in understanding the mechanisms by which they exert their protective effects. As with LEA proteins, the disordered nature of CAHS proteins and other TDPs goes against traditional intuition of structure-function analysis. However, CAHS proteins take on a glass form during desiccation, suggesting that disordered proteins in general may contribute to cellular vitrification - a mechanism we will discuss in more detail below (Boothby and Pielak, 2017; Boothby et al., 2017; Janis et al., 2018).

\section{LEA Proteins}

As well as novel TDPs, tardigrades also have genes encoding group 3 LEA proteins (Förster et al., 2009, 2012; Schokraie et al., 2010; Tanaka et al., 2015). Heterologous expression in cultured human cells, a similar approach to that used by Artemia researchers, was used along with immunolocalization in tardigrades to determine the subcellular localization of a group 3 LEA protein of Ramazzottius varieornatus, RvLEAM. This LEA is mitochondrially localized, similar to AfrLEA3m (Tanaka et al., 2015). Thus, distribution of LEA proteins to different subcellular regions may represent a widespread strategy that contributes to cellular survival.

\section{Heat Shock Proteins}

Heat shock proteins in tardigrades have been identified in several studies, and in some cases have been shown to be upregulated during anhydrobiosis (Reuner et al., 2010; Schokraie et al., 2010, 2011; Förster et al., 2012). The full repertoire of heat shock proteins seems to be conserved in tardigrades, including sHSPs and Hsp70 (Förster et al., 2009, 2012; Yoshida et al., 2017). Some of the small heat shock proteins (like Hsp27 and Hsp30c of M. tardigradum) are also upregulated during dehydration (Wang et al., 2014). In contrast, Hsp70 expression is not increased during desiccation, but is instead upregulated during rehydration and recovery (Schill et al., 2004; Jönsson and Schill, 2007; Rizzo et al., 2010; Altiero et al., 2012). This expression timeline is consistent with a possible role for Hsp70 in folding or refolding proteins to restore proteostasis following desiccation.

\section{Oxidative Stress Response}

Oxidative stress has been proposed as a factor that ultimately limits the time tardigrades can survive desiccation (Guidetti and Jönsson, 2002). There is evidence for increased superoxide dismutase activity and peroxidase activity during desiccation, as well as an overall increase in levels of the reducing agent glutathione (Rizzo et al., 2010). These changes likely counter the accumulation of oxidative damage during desiccation.

\section{DNA Preservation}

Extended time spent in anhydrobiosis leads to DNA damage, suggesting a genotoxic effect of desiccation (Neumann et al., 2009). However, short-term desiccation does not cause significant DNA damage, suggesting that animals are able to sufficiently protect DNA during the early stages of desiccation (Rebecchi et al., 2009). Tardigrades are also able to survive exposure to relatively high doses of UV, X-ray, and gamma radiation (Horikawa et al., 2013; Beltrán-Pardo et al., 2015; Hashimoto and Kunieda, 2017). These observations suggest that tardigrades exhibit DNA protection mechanisms that may function during anhydrobiosis. To preserve the integrity of their genome, tardigrades must either prevent or efficiently repair DNA damage. Components of traditional DNA damage repair pathways have been found to be present in many tardigrade species, and a novel tardigrade protein, Dsup, has been identified that suppresses DNA damage (Hashimoto et al., 2016; Yoshida et al., 2017; Carrero et al., 2019; Kamilari et al., 2019). Dsup binds to DNA and prevents fragmentation in response to X-ray irradiation, $\mathrm{H}_{2} \mathrm{O}_{2}$, and hydroxyl radicals (Hashimoto et al., 2016; Hashimoto and Kunieda, 2017; Chavez et al., 2019). Expression of Dsup in cultured human cells can improve survival of X-ray irradiation and enable subsequent proliferation (Hashimoto et al., 2016). Dsup has been investigated primarily for a role in preventing DNA damage caused by specific genotoxic agents, but it could feasibly function similarly during desiccation to preserve the integrity of DNA.

\section{Lessons From Tardigrades}

As with research on Artemia, heterologous systems and in vitro studies have predominantly fueled our understanding of the functions of tardigrade proteins. Studies of endogenous functions of tardigrade proteins have been rare. This is likely due to the limited resources currently available for reverse genetics. To date, use of RNAi for gene knockdown has been documented in only one species of tardigrade, $H$. exemplaris (Tenlen et al., 2013). Expanding such methods to other species of tardigrades will allow for more studies of endogenous functions. The lack of reliance on trehalose for desiccation tolerance and discovery of novel TDPs suggest that further mechanisms likely remain to be uncovered.

\section{COMMON MECHANISMS OF DESICCATION TOLERANCE}

Several common themes of desiccation tolerance have emerged from research in Artemia, nematodes, and tardigrades. For example, each of these three animals has genes encoding LEA proteins and heat shock proteins like Hsp70 and small heat shock proteins (see Table 1). Other mechanisms are more prominent in some animals than others. For example Artemia and C. elegans produce significant levels of trehalose, while some species of tardigrades produce none at all. In many cases, proteins found 
to function in one of these systems simply have not been tested in others. For example, Hsf1 is required for desiccation resistance in Artemia but, to date, has not been explored in either tardigrades or nematodes. In such cases research from other organisms can supplement our understanding. For example Hsfl of the anhydrobiotic midge Polypedilum vanderplanki is responsible for regulation of desiccation-responsive transcripts (Mazin et al., 2018). Finding and filling these knowledge gaps across organisms will inform the evolutionary history of desiccation resistance and reveal the extent to which regulation of the desiccation response and the protectants that allow for survival are conserved amongst anhydrobiotes. Looking beyond individual protectants, there are several generalizable mechanisms (often involving some of the molecular players already discussed) that have been proposed. Figure 2 depicts some of the common protectants and mechanisms that have been identified and their organization within a cell. So far, three key biochemical models for desiccation tolerance have emerged.

\section{Water Replacement Hypothesis}

In hydrated cells, water provides a polar solvent in which molecules with exposed hydrophilic regions are stable. The loss of water during desiccation disrupts the normal chemical interactions that maintain proteostasis, membrane stability, and other essential cellular functions. The hypothesis was put forward that by synthesizing large quantities of polar molecules like glycerol or trehalose, perhaps cells are able to simulate the types of molecular interactions (like hydrogen bonding) that would occur in an aqueous environment (Crowe and Clegg, 1973; Clegg et al., 1982). A particular example of this is the preservation of lipid bilayers by trehalose during desiccation (see Figure 2) (Crowe et al., 1984). In hydrated conditions, water surrounds phospholipid head groups, providing spacing between these polar (hydrophilic) groups (Crowe et al., 1998b). Loss of water molecules as an insulator between these phospholipids causes compression of the membrane leading to increased rigidity and ultimately fragmentation and leakage (Crowe et al., 1984, 1998b). Trehalose buffers membranes from these effects by substituting for water and associating with phospholipid head groups, thereby providing adequate spacing of phospholipids and allowing for retention of membrane fluidity (Crowe et al., 1998b; Golovina et al., 2010; Abusharkh et al., 2014). Trehalose can also preserve the morphology of lipid raft domains in drying membranes (Chiantia et al., 2005). The same types of beneficial interactions that preserve membranes may similarly protect proteins that display polar surfaces (Jain and Roy, 2009). It has also been suggested that sugars like trehalose could assist in trapping any residual water and creating a film at critical hydrophilic contact sites (Belton and Gil, 1994; Cottone et al., 2002). The function of trehalose as a "water replacement" likely overlaps with its function in forming biological glasses (Koster et al., 1994; Crowe et al., 2001, 2011; Crowe, 2007).

\section{Vitrification}

A glass is an amorphous, non-crystalline solid. Through the process of vitrification, biological glasses form and protect cells from damage during dehydration (Sun and Leopold, 1997;
Crowe et al., 1998a). During drying, vitrification creates a highly viscous matrix that spatially restricts cellular components such that chemical reactions are significantly limited (Buitink et al., 1998). This has been suggested as a means for promoting desiccation-associated metabolic quiescence (Bruni and Leopold, 1991). The process of vitrification is temperature-dependent, and different molecules have unique glass transition temperatures (Crowe et al., 1998a). Trehalose has garnered particular attention for its glass-forming properties (Crowe et al., 2001; Crowe, 2007). While trehalose is not unique in its glass-forming ability, it has a higher glass transition temperature than other sugars - meaning that only at high temperatures will it "melt" and dissolve the glass into a more fluid state (Green and Angell, 1989; Crowe et al., 1998a). In addition to sugars, some proteins have been shown to contribute to glass formation. LEA proteins contribute to biological glass formation and can act synergistically with trehalose to confer desiccation tolerance (Wolkers et al., 2001; Shimizu et al., 2010). Disordered CAHS proteins from tardigrades can also vitrify (Boothby et al., 2017).

Evidence for glassy solids in plants and animals, including Artemia and tardigrades, suggest that glass formation is a widespread mechanism contributing to desiccation tolerance (Williams and Leopold, 1989; Sakurai et al., 2008; Hengherr et al., 2009, 2011a; Boothby et al., 2017). While some examples of the molecules that allow for vitrification have been discovered, there are likely more components that contribute to cellular glass formation that remain to be uncovered. Our understanding of the physiology of vitrification will grow as organismal and biochemical studies converge.

\section{Molecular Shielding}

The term "molecular shield" was first proposed to describe the function of LEA proteins that may provide a protective shell that shields proteins during desiccation and prevent aggregation (Wise and Tunnacliffe, 2004; Goyal et al., 2005). The proposed function of a molecular shield protein is to limit the number and frequency of intermolecular interactions that could lead to protein aggregation during desiccation (Liu et al., 2011; Chakrabortee et al., 2012; Hatanaka et al., 2013). This function is similar to that of classic molecular chaperones like some HSPs - for example small heat shock proteins that can nonenzymatically limit protein aggregation by creating a similar "shield" around misfolded proteins and prevent interactions with neighboring proteins that would otherwise coalesce into aggregates (Tunnacliffe and Wise, 2007; Haslbeck et al., 2019). Notably, molecular shielding has been reserved primarily as a descriptor for the function of disordered proteins with nonspecific binding partners (Chakrabortee et al., 2012). Whereas some chaperones like Hsp70 specifically bind to client proteins that need to be refolded, LEAs and other shield proteins are thought to bind less specifically, but rather offer a general buffer by slowing the rate of protein-protein interaction that may lead to aggregation (Liu et al., 2011; Chakrabortee et al., 2012).

\section{Mechanistic Synergy}

While the water replacement hypothesis, vitrification, and molecular shielding are sometimes discussed as individual 
mechanisms for desiccation survival, they likely overlap and synergistically promote desiccation tolerance. This can be appreciated when individual molecular protectants contribute to more than one of these models. For example, LEA proteins contribute to each of the three models for protection, and trehalose plays a prominent role in both the water replacement hypothesis and vitrification (Hand et al., 2011). Thus, fitting individual protectants into a single mechanistic model may be too simplistic. Further, some studies have found synergy between protectants like trehalose, IDPs, p26, and LEA proteins (Goyal et al., 2005; Ma et al., 2005; Kim et al., 2018). The three models discussed share some common protectant molecules and may in fact be largely one coherent mechanism. For example, as LEA proteins are incorporated into amorphous biological glasses, they are dispersed throughout the cell and can slow molecular interactions as they shield aggregation-prone proteins in a glassy matrix, and at the same time provide stability to polar molecules with their amphipathic or hydrophilic structure (Tunnacliffe and Wise, 2007).

\section{DISCUSSION}

\section{Conclusion}

Our knowledge of the mechanisms of desiccation tolerance has been largely informed by research on a small number of anhydrobiotic organisms. Work on Artemia, nematodes, and tardigrades has advanced our understanding of the protectants and mechanisms that contribute to desiccation survival. Comparisons of the types of protectants involved in desiccation tolerance in each animal converges on a few key molecules (see Table 1). However, there are noteworthy variations to these common molecular and mechanistic themes: examples like tardigrades apparently lacking trehalose and the Artemia-specific protein, Artemin. Each organism has brought with it unique experimental advantages as well Artemia have a unique life cycle and intergenerational diapause, C. elegans has provided a genetic model to greatly facilitate gene identification and functional studies, and tardigrades are emerging as another model for exceptional stress tolerance. A comparative organismal approach to the study of desiccation tolerance, using these organisms and others such as rotifers and midges, has enriched our understanding of mechanisms that multicellular organisms employ to survive desiccation, and no doubt will continue to do so.

\section{Open Questions}

Desiccation tolerance is sometimes conceived as primarily a cellular survival strategy. While individual cells must synthesize

\section{REFERENCES}

Abusharkh, S. E., Erkut, C., Oertel, J., Kurzchalia, T. V., and Fahmy, K. (2014). The role of phospholipid headgroup composition and trehalose in the desiccation tolerance of Caenorhabditis elegans. Langmuir 30, 12897-12906. doi: 10.1021/ la502654j the necessary protectants to survive, the coordination of the desiccation response in multicellular organisms presents an expanded set of challenges - to sense and respond appropriately to environmental cues that signal dehydration, and coordinate a response across tissues to allow the animal to survive. This necessitates exquisite spatial and temporal regulation. While some mechanisms by which this sensing and coordination are accomplished have been discussed, the basis of the intermediate regulatory steps between survival of an organism and survival of a cell remain largely unknown.

In many cases, heterologous expression of proteins demonstrates the possible activity of protectants for desiccation survival. However, the endogenous functions of proteins are often poorly characterized. Conducting more in vivo experiments and drawing conclusions about protectants in their native context will help to distinguish between possible protectants and those that are essential. Still, part of the promise in studying mechanisms of desiccation tolerance is the application of discoveries to better preserve biomaterials. Therefore, discovery of new, uncharacterized protectants continues to be of interest. In over 300 years since the initial observation of desiccation survival, our understanding has grown considerably. Yet, in many ways the molecular basis of anhydrobiosis and mechanisms by which multicellular animals survive drying are only beginning to emerge. Continued research in Artemia, nematodes, and tardigrades in coming years will likely contribute significantly to our growing understanding of desiccation tolerance.

\section{AUTHOR CONTRIBUTIONS}

JH drafted the original manuscript. All authors edited and revised the manuscript, approved the final version, and contributed to the conception of this review and discussion of its contents.

\section{FUNDING}

JH was supported by the National Institutes of Health (F32 GM131577). Desiccation tolerance research from BG and JH was supported by National Science Foundation grants (IOS 1557432 and 2028860).

\section{ACKNOWLEDGMENTS}

We thank Patrick Sorgeloos for sharing the image of a hatching nauplius larva of Artemia in Figure 1B and Courtney ClarkHachtel for comments on the manuscript.

Adhikari, B. N., Wall, D. H., and Adams, B. J. (2009). Desiccation survival in an Antarctic nematode: molecular analysis using expressed sequenced tags. BMC Genomics 10:69. doi: 10.1186/1471-2164-10-69

Altiero, T., Guidetti, R., Boschini, D., and Rebecchi, L. (2012). Heat shock proteins in encysted and anhydrobiotic eutardigrades. J. Limnol. 71, 211-215. doi: 10. 4081/jlimnol.2012.e22 
Anderson, E., Lochhead, J. H., Lochhead, M. S., and Huebner, E. (1970). The origin and structure of the tertiary envelope in thick-shelled eggs of the Brine Shrimp, Arternia. J. Ultrasructure Res. 525, 497-525.

Argüelles, J. C. (2014). Why can't vertebrates synthesize trehalose? J. Mol. Evol. 79, 111-116. doi: 10.1007/s00239-014-9645-9

Baker, J., Van dennSteele, C., and Dure, L. (1988). Sequence and characterization of 6 Lea proteins and their genes from cotton. Plant Mol. Biol. 11, 277-291. doi: 10.1007/BF00027385

Banton, M. C., and Tunnacliffe, A. (2012). MAPK phosphorylation is implicated in the adaptation to desiccation stress in nematodes. J. Exp. Biol. 215, 4288-4298. doi: $10.1242 /$ jeb. 074799

Battaglia, M., Olvera-Carrillo, Y., Garciarrubio, A., Campos, F., and Covarrubias, A. A. (2008). The enigmatic LEA proteins and other hydrophilins. Plant Physiol. 148, 6-24. doi: 10.1104/pp.108.120725

Behm, C. A. (1997). The role of trehalose in the physiology of nematodes. Int. J. Parasitol. 27, 215-229. doi: 10.1016/S0020-7519(96)00151-8

Belton, P. S., and Gil, A. M. (1994). IR and Raman spectroscopic studies of the interaction of trehalose with hen egg white lysozyme. Biopolymers 34, 957-961. doi: 10.1002/bip.360340713

Beltrán-Pardo, E., Jönsson, K. I., Harms-Ringdahl, M., Haghdoost, S., and Wojcik, A. (2015). Tolerance to gamma radiation in the tardigrade hypsibius dujardini from embryo to adult correlate inversely with cellular proliferation. PLoS One 10:e0133658. doi: 10.1371/journal.pone.0133658

Berenbaum, M. (1999). Sea Monkey ${ }^{\circledR}$ See, Sea Monkey ${ }^{\circledR}$ Do. Am. Entomol. 45, 68-69.

Bertolani, R., Guidetti, R., Jönsson, I., Altiero, T., Boschini, D., and Rebecchi, L. (2004). Experiences with dormancy in tardigrades. J. Limnol. 63, 16-25. doi: $10.4081 /$ jlimnol.2004.s1.16

Boothby, T., Tapia, H., Brozena, A. H., Piszkiewicz, S., Smith, A. E., Giovannini, I., et al. (2017). Tardigrades use intrinsically disordered proteins to survive desiccation. Mol. Cell. Mol. Cell 65, 975-984. doi: 10.1016/j.molcel.2017.02.018

Boothby, T. C., and Pielak, G. J. (2017). Intrinsically disordered proteins and desiccation tolerance: elucidating functional and mechanistic underpinnings of anhydrobiosis. BioEssays 39, 1-4. doi: 10.1002/bies.201700119

Boswell, L. C., and Hand, S. C. (2014). Intracellular localization of group 3 LEA proteins in embryos of Artemia franciscana. Tissue Cell 46, 514-519. doi: 10. 1016/j.tice.2014.09.004

Boswell, L. C., Menze, M. A., and Hand, S. C. (2014a). Group 3 late embryogenesis abundant proteins from embryos of Artemia franciscana: structural properties and protective abilities during desiccation. Physiol. Biochem. Zool. 87, 640-651. doi: $10.1086 / 676936$

Boswell, L. C., Moore, D. S., and Hand, S. C. (2014b). Quantification of cellular protein expression and molecular features of group 3 LEA proteins from embryos of Artemia franciscana. Cell Stress Chaperones 19, 329-341. doi: 10. 1007/s12192-013-0458-3

Braeckman, B. P., Houthoofd, K., and Vanfleteren, J. R. (2009). Intermediary metabolism. WormBook 1-24. doi: 10.1895/wormbook.1.146.1

Brenner, S. (1974). The genetics of Caenorhabditis elegans. Genetics 77, 71-94.

Browne, J., Tunnacliffe, A., and Burnell, A. (2002). Plant desiccation gene found in a nematode. Nature 416:38. doi: 10.1038/416038a

Browne, J. A., Dolan, K. M., Tyson, T., Goyal, K., Tunnacliffe, A., and Burnell, A. M. (2004). Dehydration-specific induction of hydrophilic protein genes in the anhydrobiotic nematode Aphelenchus avenae. Eukaryot. Cell 3, 966-975. doi: 10.1128/EC.3.4.966-975.2004

Bruni, F., and Leopold, A. C. (1991). Glass transitions in soybean seed: relevance to anhydrous biology. Plant Physiol. 96, 660-663. doi: 10.1104/pp.96.2.660

Brunquell, J., Morris, S., Lu, Y., Cheng, F., and Westerheide, S. D. (2016). The genome-wide role of HSF-1 in the regulation of gene expression in Caenorhabditis elegans. BMC Genomics 17:559. doi: 10.1186/s12864-016-28375

Buitink, J., Claessens, M. M. A. E., Hemminga, M. A., and Hoekstra, F. A. (1998). Influence of water content and temperature on molecular mobility and intracellular glasses in seeds and pollen. Plant Physiol. 118, 531-541. doi: 10.1104/pp.118.2.531

Burnell, A. M., Houthoofd, K., O'Hanlon, K., and Vanfleteren, J. R. (2005). Alternate metabolism during the dauer stage of the nematode Caenorhabditis elegans. Exp. Gerontol. 40, 850-856. doi: 10.1016/j.exger.2005.09.006
Busa, W. B., and Crowe, J. H. (1983). Intracellular pH regulates transitions between dormancy and development of Brine Shrimp (Artemia salina) embryos. Science 221, 366-368.

Busa, W. B., Crowe, J. H., and Matson, G. B. (1982). Intracellular pH and the metabolic status of dormant and developing Artemia Embryos. Arch. Biochem. Biophys. 216, 711-718.

Carrero, D., Pérez-Silva, J. G., Quesada, V., and López-Otín, C. (2019). Differential mechanisms of tolerance to extreme environmental conditions in tardigrades. Sci. Rep. 9, 1-11. doi: 10.1038/s41598-019-51471-8

Cassada, R. C., and Russell, R. L. (1975). The dauerlarva, a post-embryonic developmental variant of the nematode Caenorhabditis elegans. Dev. Biol. 46, 326-342. doi: 10.1016/0012-1606(75)90109-8

Cesari, M., Altiero, T., and Rebecchi, L. (2012). Identification of the trehalose6-phosphate synthase (tps) gene in desiccation tolerant and intolerant tardigrades. Ital. J. Zool. 79, 530-540. doi: 10.1080/11250003.2012.703248

Chakrabortee, S., Boschetti, C., Walton, L. J., Sarkar, S., Rubinsztein, D. C., and Tunnacliffe, A. (2007). Hydrophilic protein associated with desiccation tolerance exhibits broad protein stabilization function. Proc. Natl. Acad. Sci. U.S.A. 104, 18073-18078. doi: 10.1073/pnas.0706964104

Chakrabortee, S., Tripathi, R., Watson, M., Kaminski Schierle, G. S., Kurniawan, D. P., Kaminski, C. F., et al. (2012). Intrinsically disordered proteins as molecular shields. Mol. Biosyst. 8, 210-219. doi: 10.1039/c1mb05263b

Chavez, C., Cruz-Becerra, G., Fei, J., Kassavetis, G. A., and Kadonaga, J. T. (2019). The tardigrade damage suppressor protein binds to nucleosomes and protects dna from hydroxyl radicals. eLife 8, 1-20. doi: 10.7554/eLife.47682

Chen, T., Amons, R., Clegg, J. S., Warner, A. H., and MacRae, T. H. (2003). Molecular characterization of artemin and ferritin from Artemia franciscana. Eur. J. Biochem. 270, 137-145. doi: 10.1046/j.1432-1033.2003.03373.x

Chen, T., Villeneuve, T. S., Garant, K. A., Amons, R., and MacRae, T. H. (2007). Functional characterization of artemin, a ferritin homolog synthesized in Artemia embryos during encystment and diapause. FEBS J. 274, 1093-1101. doi: 10.1111/j.1742-4658.2007.05659.x

Chiantia, S., Kahya, N., and Schwille, P. (2005). Dehydration damage of domainexhibiting supported bilayers: an AFM study on the protective effects of disaccharides and other stabilizing substances. Langmuir 21, 6317-6323. doi: $10.1021 / \mathrm{la} 050115 \mathrm{~m}$

Clegg, J. S. (1962). Free glycerol in dormant cysts of the Brine Shrimp Artemia salina, and its disappearance during development. Biol. Bull. 123, 295-301. doi: $10.2307 / 1539275$

Clegg, J. S. (1964). The control of emergence and metabolism by external osmotic pressure and the role of free glycerol in developing cysts of Artemia salina. J. Exp. Biol. 41, 879-892.

Clegg, J. S. (1965). The origin of trehalose and its significance during the formation of encysted dormant embryos of Artmia salina. Comp. Biochem. Physiol. 14, 135-143. doi: 10.1016/0010-406X(65)90014-9

Clegg, J. S. (1966). Protein synthesis in the absence of cell division during the development of artemia salina embryos. Nature 212, 517-519. doi: 10.1038/ $212517 \mathrm{a} 0$

Clegg, J. S. (1967). Metabolic studies of crytobiosis in encysted embryos of Artemia salina. Comp. Biochem. Physiol. 20, 801-809. doi: 10.1016/0010-406X(67) 90054-0

Clegg, J. S. (1974). Interrelationships between water and metabolism in Artemia salina cysts: hydration dehydration from the liquid and vapour phases. J. Exp. Biol. 61, 291-308.

Clegg, J. S. (1997). Embryos of Artemia franciscana survive four years of continuous anoxia: the case for complete metabolic rate depression. J. Exp. Biol. 200, 467-475.

Clegg, J. S. (2005). Desiccation tolerance in encysted embryos of the animal extremophile, Artemia. Integr. Comp. Biol. 45, 715-724. doi: 10.1093/icb/45.5. 715

Clegg, J. S., and Cavagnaro, J. (1976). Interrelationships between water and cellular metabolism in Artemia cysts - IV. Adenosine 5'-triphosphate and cyst hydration. J. Cell. Physiol. 88, 159-166.

Clegg, J. S., Jackson, S. A., Liang, P., and Macrae, T. H. (1995). Nuclearcytoplasmic translocations of protein p26 during aerobic-anoxic transitions in embryos of Artemia franciscana. Exp. Cell Res. 219, 1-7. doi: 10.1006/excr.1995. 1197 
Clegg, J. S., Seitz, P., Seitz, W., and Hazlewood, C. F. (1982). Cellular responses to extreme water loss: the water-replacement hypothesis. Cryobiology 19, 306-316. doi: 10.1016/0011-2240(82)90159-6

Clegg, J. S., Willsie, J. K., and Jackson, S. A. (1999). Adaptive significance of a small heat shock/a-crystallin protein (p26) in encysted embryos of the brine shrimp, artemia franciscana. Am. Zool. 39, 836-847. doi: 10.1093/icb/39.6.836

Colbert, H. A., Smith, T. L., and Bargmann, C. I. (1997). OSM-9, a novel protein with structural similarity to channels, is required for olfaction, mechanosensation, and olfactory adaptation in Caenorhabditis elegans. J. Neurosci. 17, 8259-8269. doi: 10.1523/jneurosci.17-21-08259.1997

Collins, C. H., and Clegg, J. S. (2004). A small heat-shock protein, p26, from the crustacean Artemia protects mammalian cells (Cos-1) against oxidative damage. Cell Biol. Int. 28, 449-455. doi: 10.1016/j.cellbi.2004.03.014

Cottone, G., Ciccotti, G., and Cordone, L. (2002). Protein-trehalose-water structures in trehalose coated carboxy-myoglobin. J. Chem. Phys. 117, 98629866. doi: 10.1063/1.1518960

Crowe, J., and Clegg, J. (1973). Anhydrobiosis. Stroudsburg, PA: Hutchinson \& Ross.

Crowe, J. H. (1972). Evaporative water loss by tardigrades under controlled relative humidities. Biol. Bull. 142, 407-416. doi: 10.2307/1540318

Crowe, J. H. (2007). Trehalose as a "chemical chaperone": fact and fantasy. Adv. Exp. Med. Biol. 594, 143-158. doi: 10.1007/978-0-387-399 75-1-13

Crowe, J. H., Carpenter, J. F., and Crowe, L. M. (1998a). The role of vitrification in anhydrobiosis. Annu. Rev. Physiol. 60, 73-103. doi: 10.1146/annurev.physiol. 60.1 .73

Crowe, J. H., Clegg, J. S., and Crowe, L. M. (1998b). “Anhydrobiosis: the water replacement hypothesis," in The Properties of Water in Foods ISOPOW 6, ed. D. S. Reid (Boston, MA: Springer), 440-455. doi: 10.1007/978-1-4613-0311-4_ 20

Crowe, J. H., Crowe, L. M., Carpenter, J. E., Petrelski, S., Hoekstra, F. A., De Araujo, P., et al. (2011). Anhydrobiosis: cellular adaptation to extreme dehydration. Compr. Physiol. 1445-1477. doi: 10.1002/cphy.cp130220

Crowe, J. H., Crowe, L. M., and Chapman, D. (1984). Preservation of membranes in anhydrobiotic organisms: the role of trehalose. Science 223, 701-703. doi: 10.1126/science.223.4637.701

Crowe, J. H., Crowe, L. M., Oliver, A. E., Tsvetkova, N., Wolkers, W., and Tablin, F. (2001). The trehalose myth revisited: introduction to a symposium on stabilization of cells in the dry state. Cryobiology 43, 89-105. doi: 10.1006/cryo. 2001.2353

Crowe, J. H., Madin, K. A. C., and Loomis, S. H. (1977). Anhydrobiosis in nematodes: metabolism during resumption of activity. J. Exp. Zool. 201, 57-64. doi: 10.1002/jez.1402010107

Crowe, J. H., McKersie, B. D., and Crowe, L. M. (1989). Effects of free fatty acids and transition temperature on the stability of dry liposomes. Biochim. Biophys. Acta 979, 7-10. doi: 10.1016/0005-2736(89)90516-6

Crowe, L. M. (2002). Lessons from nature: the role of sugars in anhydrobiosis. Comp. Biochem. Physiol. A Mol. Integr. Physiol. 131, 505-513. doi: 10.1016/ S1095-6433(01)00503-7

Czerneková, M., Jönsson, K. I., Chajec, L., Student, S., and Poprawa, I. (2017). The structure of the desiccated Richtersius coronifer (Richters, 1903). Protoplasma 254, 1367-1377. doi: 10.1007/s00709-016-1027-2

Czernik, M., Fidanza, A., Luongo, F. P., Valbonetti, L., Scapolo, P. A., Patrizio, P., et al. (2020). Late Embryogenesis Abundant (LEA) proteins confer water stress tolerance to mammalian somatic cells. Cryobiology 92, 189-196. doi: 10.1016/j.cryobiol.2020.01.009

Dai, L., Chen, D. F., Liu, Y. L., Zhao, Y., Yang, F., Yang, J. S., et al. (2011). Extracellular matrix peptides of artemia cyst shell participate in protecting encysted embryos from extreme environments. PLoS One 6:e0020187. doi: 10. 1371/journal.pone.0020187

De Graaf, J., Amons, R., and Möller, W. (1990). The primary structure of artemin from Artemia cysts. Eur. J. Biochem. 193, 737-741. doi: 10.1111/j.1432-1033. 1990.tb19394.x

Dickinson, D. J., Ward, J. D., Reiner, D. J., and Goldstein, B. (2013). Engineering the Caenorhabditis elegans genome using Cas9-triggered homologous recombination. Nat. Methods 10, 1028-1034. doi: 10.1038/nmeth. 2641
Drinkwater, L. E., and Crowe, J. H. (1987). Regulation of embryonic diapause in Artemia: environmental and physiological signals. J. Exp. Zool. 241, 297-307. doi: 10.1002/jez.1402660611

Dure, L., Greenway, S. C., and Galau, G. A. (1981). Developmental biochemistry of cottonseed embryogenesis and germination: changing messenger ribonucleic acid populations as shown by in vitro and in vivo protein synthesis. Biochemistry 20, 4162-4168. doi: 10.1021/bi00517a033

Enjin, A., Zaharieva, E. E., Frank, D. D., Mansourian, S., Suh, G. S. B., Gallio, M., et al. (2016). Humidity sensing in drosophila. Curr. Biol. 26, 1352-1358. doi: 10.1016/j.cub.2016.03.049

Erkut, C., Gade, V. R., Laxman, S., and Kurzchalia, T. V. (2016). The glyoxylate shunt is essential for desiccation tolerance in $\mathrm{C}$. elegans and budding yeast. eLife 5:e13614. doi: 10.7554/eLife.13614

Erkut, C., and Kurzchalia, T. V. (2015). The C. elegans dauer larva as a paradigm to study metabolic suppression and desiccation tolerance. Planta 242, 389-396. doi: 10.1007/s00425-015-2300-x

Erkut, C., Penkov, S., Khesbak, H., Vorkel, D., Verbavatz, J. M., Fahmy, K., et al. (2011). Trehalose renders the dauer larva of caenorhabditis elegans resistant to extreme desiccation. Curr. Biol. 21, 1331-1336. doi: 10.1016/j.cub.2011. 06.064

Erkut, C., Vasilj, A., Boland, S., Habermann, B., Shevchenko, A., and Kurzchalia, T. V. (2013). Molecular strategies of the Caenorhabditis elegans dauer larva to survive extreme desiccation. PLoS One 8:e0082473. doi: 10.1371/journal.pone. 0082473

Förster, F., Beisser, D., Grohme, M. A., Liang, C., Mali, B., Siegl, A. M., et al. (2012). Transcriptome analysis in tardigrade species reveals specific molecular pathways for stress adaptations. Bioinform. Biol. Insights 6, 69-95. doi: 10.4137/ BBI.S9150

Förster, F., Liang, C., Shkumatov, A., Beisser, D., Engelmann, J. C., Schnölzer, M., et al. (2009). Tardigrade workbench: comparing stress-related proteins, sequence-similar and functional protein clusters as well as RNA elements in tardigrades. BMC Genomics 10:469. doi: 10.1186/1471-2164-10-469

França, M. B., Panek, A. D., and Eleutherio, E. C. A. (2007). Oxidative stress and its effects during dehydration. Comp. Biochem. Physiol. A Mol. Integr. Physiol. 146, 621-631. doi: 10.1016/j.cbpa.2006.02.030

Fukuda, Y., Miura, Y., Mizohata, E., and Inoue, T. (2017). Structural insights into a secretory abundant heat-soluble protein from an anhydrobiotic tardigrade, Ramazzottius varieornatus. FEBS Lett. 591, 2458-2469. doi: 10.1002/1873-3468. 12752

Gal, T. Z., Glazer, I., and Koltai, H. (2004). An LEA group 3 family member is involved in survival of C. elegans during exposure to stress. FEBS Lett. 577, 21-26. doi: 10.1016/j.febslet.2004.09.049

Gal, T. Z., Glazer, I., and Koltai, H. (2006). Differential gene expression during desiccation stress in the insect-killing nematode steinernema feltiae Is-6. J. Parasitol. 89, 761-766. doi: 10.1645/ge-3105

Gasiorek, P., Stec, D., Morek, W., and Michalczyk, Ł (2018). An integrative redescription of Hypsibius dujardini (Doyère, 1840), the nominal taxon for Hypsibioidea (Tardigrada: Eutardigrada). Zootaxa 4415, 45-75. doi: 10.11646/ zootaxa.4415.1.2

Giménez-Andrés, M., Èopiè, A., and Antonny, B. (2018). The many faces of amphipathic helices. Biomolecules 8, 1-14. doi: 10.3390/biom8030045

Goldstein, B. (2018). The emergence of the tardigrade hypsibius exemplaris as a model system. Cold Spring Harb. Protoc. 2018, 859-866. doi: 10.1101/pdb. emo102301

Goldstein, B., and Blaxter, M. (2002). Quick guide Tardigrades. Curr. Biol. 12, $475-475$.

Golovina, E. A., Golovin, A., Hoekstra, F. A., and Faller, R. (2010). Water replacement hypothesis in atomic details: effect of trehalose on the structure of single dehydrated POPC bilayers. Langmuir 26, 11118-11126. doi: 10.1021/ la100891x

Goyal, K., Tisi, L., Basran, A., Browne, J., Burnell, A., Zurdo, J., et al. (2003). Transition from natively unfolded to folded state induced by desiccation in an anhydrobiotic nematode protein. J. Biol. Chem. 278, 12977-12984. doi: 10.1074/ jbc.M212007200

Goyal, K., Walton, L. J., and Tunnacliffe, A. (2005). LEA proteins prevent protein aggregation due to water stress. Biochem. J. 388, 151-157. doi: 10.1042/ BJ20041931 
Green, J. L., and Angell, C. A. (1989). Phase relations and vitrification in saccharide-water solutions and the trehalose anomaly. J. Phys. Chem. 93, 2880-2882. doi: $10.1021 / \mathrm{j} 100345 \mathrm{a} 006$

Grohme, M. A., Mali, B., Schill, R. O., and Frohme, M. (2011). cDNA representational difference analysis for identifying transcripts regulated under anhydrobiosis in the tardigrade Milnesium tardigradum. J. Zool. Syst. Evol. Res. 49, 127-132. doi: 10.1111/j.1439-0469.2010.00610.x

Guidetti, R., and Jönsson, K. I. (2002). Long-term anhydrobiotic survival in semi-terrestrial micrometazoans. J. Zool. 257, 181-187. doi: 10.1017/ S095283690200078X

Guidetti, R., Rizzo, A. M., Altiero, T., and Rebecchi, L. (2012). What can we learn from the toughest animals of the Earth? Water bears (tardigrades) as multicellular model organisms in order to perform scientific preparations for lunar exploration. Planet. Space Sci. 74, 97-102. doi: 10.1016/j.pss.2012.05.021

Guo, N., Puhlev, I., Brown, D. R., Mansbridge, J., and Levine, F. (2000). Trehalose expression confers desiccation tolerance on human cells. Nat. Biotechnol. 18, 168-171. doi: 10.1038/72616

Halberg, K. A., Jørgensen, A., and Møbjerg, N. (2013). Desiccation tolerance in the tardigrade Richtersius coronifer relies on muscle mediated structural reorganization. PLoS One 8:e0085091. doi: 10.1371/journal.pone.0085091

Hand, S. C., Jones, D., Menze, M. A., and Witt, T. L. (2006). Life without water: expression of plant LEA genes by an anhydrobiotic arthropod. J. Exp. Zool. 307A, 62-66. doi: 10.1002/jez.a

Hand, S. C., and Menze, M. A. (2015). Molecular approaches for improving desiccation tolerance: insights from the brine shrimp Artemia franciscana. Planta 242, 379-388. doi: 10.1007/s00425-015-2281-9

Hand, S. C., Menze, M. A., Toner, M., Boswell, L., and Moore, D. (2011). LEA proteins during water stress: not just for plants anymore. Annu. Rev. Physiol. 73, 115-134. doi: 10.1146/annurev-physiol-012110-142203

Hashimoto, T., Horikawa, D. D., Saito, Y., Kuwahara, H., Kozuka-Hata, H., Shin-I, T., et al. (2016). Extremotolerant tardigrade genome and improved radiotolerance of human cultured cells by tardigrade-unique protein. Nat. Commun. 7:12808. doi: 10.1038/ncomms 12808

Hashimoto, T., and Kunieda, T. (2017). DNA protection protein, a novel mechanism of radiation tolerance: lessons from tardigrades. Life 7, 1-12. doi: 10.3390/life7020026

Haslbeck, M. (2002). sHsps and their role in the chaperone network. Cell. Mol. Life Sci. 59, 1649-1657.

Haslbeck, M., Weinkauf, S., and Buchner, J. (2019). Small heat shock proteins: simplicity meets complexity. J. Biol. Chem. 294, 2121-2132. doi: 10.1074/jbc. REV118.002809

Hatanaka, R., Hagiwara-Komoda, Y., Furuki, T., Kanamori, Y., Fujita, M., Cornette, R., et al. (2013). An abundant LEA protein in the anhydrobiotic midge, PvLEA4, acts as a molecular shield by limiting growth of aggregating protein particles. Insect Biochem. Mol. Biol. 43, 1055-1067. doi: 10.1016/j.ibmb. 2013.08.004

Hengherr, S., Heyer, A. G., Kohler, H. R., and Schill, R. O. (2008). Trehalose and anhydrobiosis in tardigrades - evidence for divergence in responses to dehydration. FEBS J. 275, 281-288. doi: 10.1111/j.1742-4658.2007.06198.x

Hengherr, S., Schill, R. O., and Clegg, J. S. (2011a). Mechanisms associated with cellular desiccation tolerance in the animal extremophile Artemia. Physiol. Biochem. Zool. 84, 249-257. doi: 10.1086/659314

Hengherr, S., Schill, R. O., and Clegg, J. S. (2011b). Mechanisms associated with cellular desiccation tolerance of Artemia encysted embryos from locations around the world. Comp. Biochem. Physiol. A Mol. Integr. Physiol. 160, 137-142. doi: 10.1016/j.cbpa.2011.05.032

Hengherr, S., Worland, M. R., Reuner, A., Brümmer, F., and Schill, R. O. (2009). High-temperature tolerance in anhydrobiotic tardigrades is limited by glass transition. Physiol. Biochem. Zool. 82, 749-755. doi: 10.1086/605954

Hibshman, J. D., Doan, A. E., Moore, B. T., Kaplan, R. E., Hung, A., Webster, A. K., et al. (2017). daf-16/FoxO promotes gluconeogenesis and trehalose synthesis during starvation to support survival. eLife 6, 1-29. doi: 10.7554/eLife.30057

Honda, Y., Tanaka, M., and Honda, S. (2010). Trehalose extends longevity in the nematode Caenorhabditis elegans. Aging Cell 9, 558-569. doi: 10.1111/j.14749726.2010.00582.x

Horikawa, D. D., Cumbers, J., Sakakibara, I., Rogoff, D., Leuko, S., Harnoto, R., et al. (2013). Analysis of DNA repair and protection in the tardigrade
Ramazzottius varieornatus and Hypsibius dujardini after exposure to UVC radiation. PLoS One 8:e064793. doi: 10.1371/journal.pone.0064793

Hsu, A.-L., Murphy, C. T., and Kenyon, C. (2003). Regulation of aging and agerelated disease by DAF-16 and heat-shock factor. Science 300, 1142-1145. doi: $10.1126 /$ science. 1083701

Hu, P. J. (2007). Dauer. WormBook 1-19. doi: 10.1895/wormbook.1.144.1

Hu, Y., Bojikova-Fournier, S., King, A. M., and MacRae, T. H. (2011). The structural stability and chaperone activity of artemin, a ferritin homologue from diapause-destined Artemia embryos, depend on different cysteine residues. Cell Stress Chaperones 16, 133-141. doi: 10.1007/s12192-010-0225-7

Hygum, T. L., Clausen, L. K. B., Halberg, K. A., Jorgensen, A., and Mobjerg, N. (2016). Tun formation is not a prerequisite for desiccation tolerance in the marine tidal tardigrade Echiniscoides sigismundi. Zool. J. Linn. Soc. 178, 907-911. doi: 10.1111/zoj.12444

Iryani, M. T. M., MacRae, T. H., Panchakshari, S., Tan, J., Bossier, P., Wahid, M. E. A., et al. (2017). Knockdown of heat shock protein 70 (Hsp70) by RNAi reduces the tolerance of Artemia franciscana nauplii to heat and bacterial infection. J. Exp. Mar. Bio. Ecol. 487, 106-112. doi: 10.1016/j.jembe.2016.12.004

Iryani, M. T. M., Sorgeloos, P., Danish-Daniel, M., Tan, M. P., Wong, L. L., Mok, W. J., et al. (2020). Cyst viability and stress tolerance upon heat shock protein 70 knockdown in the brine shrimp Artemia franciscana. Cell Stress Chaperones doi: 10.1007/s12192-020-01113-0 [Epub ahead of print]

Jackson, S. A., and Clegg, J. S. (1996). Ontogeny of low molecular weight stress protein p26 during early development of the brine shrimp, Artemia franciscana. Dev. Growth Differ. 38, 153-160. doi: 10.1046/j.1440-169X.1996.t01-1-00004.x

Jain, N. K., and Roy, I. (2009). Effect of trehalose on protein structure. Protein Sci. 18, 24-36. doi: 10.1002/pro.3

Jakob, U., Gaestel, M., Engel, K., and Buchner, J. (1993). Small heat shock proteins are molecular chaperones. J. Biol. Chem. 268, 1517-1520.

Janis, B., Belott, C., and Menze, M. A. (2018). Role of intrinsic disorder in animal desiccation tolerance. Proteomics 18, 1-15. doi: 10.1002/pmic.201800067

Janis, B., Uversky, V. N., and Menze, M. A. (2017). Potential functions of LEA proteins from the brine shrimp Artemia franciscana - anhydrobiosis meets bioinformatics. J. Biomol. Struct. Dyn. 1102, 1-19. doi: 10.1080/07391102.2017. 1387177

Jiang, G., Rowarth, N. M., Panchakshari, S., and MacRae, T. H. (2016). ArHsp40, a type $1 \mathrm{~J}$-domain protein, is developmentally regulated and stress inducible in post-diapause Artemia franciscana. Cell Stress Chaperones 21, 1077-1088. doi: 10.1007/s12192-016-0732-2

Jonsson, K. I., and Persson, O. (2010). Trehalose in three species of desiccation tolerant tardigrades. Open Zool. J. 3, 1-5. doi: 10.2174/1874336601003010001

Jönsson, K. I., Rabbow, E., Schill, R. O., Harms-Ringdahl, M., and Rettberg, P. (2008). Tardigrades survive exposure to space in low Earth orbit. Curr. Biol. 18, 729-731. doi: 10.1016/j.cub.2008.06.048

Jönsson, K. I., and Schill, R. O. (2007). Induction of Hsp70 by desiccation, ionising radiation and heat-shock in the eutardigrade Richtersius coronifer. Comp. Biochem. Physiol. B Biochem. Mol. Biol. 146, 456-460. doi: 10.1016/j.cbpb.2006. 10.111

Junprung, W., Norouzitallab, P., De Vos, S., Tassanakajon, A., Nguyen Viet, D., Van Stappen, G., et al. (2019). Sequence and expression analysis of HSP70 family genes in Artemia franciscana. Sci. Rep. 9, 1-13. doi: 10.1038/s41598-01944884-y

Kamilari, M., Jørgensen, A., Schiøtt, M., and Møbjerg, N. (2019). Comparative transcriptomics suggest unique molecular adaptations within tardigrade lineages. BMC Genomics 20:607. doi: 10.1186/s12864-019-5912-x

Kampinga, H. H., and Craig, E. A. (2010). The HSP70 chaperone machinery: J proteins as drivers of functional specificity. Nat. Rev. Mol. Cell Biol. 11, 579-592. doi: $10.1038 / \mathrm{nrm} 2941$

Keilin, D. (1959). The problem of anabiosis or latent life: history and current concept. Proc. R. Soc. B Biol. Sci. 150, 149-191. doi: 10.1098/rspb.1959. 0013

Kikawada, T., Nakahara, Y., Kanamori, Y., Iwata, K. I., Watanabe, M., McGee, B., et al. (2006). Dehydration-induced expression of LEA proteins in an anhydrobiotic chironomid. Biochem. Biophys. Res. Commun. 348, 56-61. doi: 10.1016/j.bbrc.2006.07.003

Kim, K. K., Kim, R., and Kim, S. H. (1998). Crystal structure of a small heat-shock protein. Nature 394, 595-599. doi: 10.1038/29106 
Kim, S. X., Çamdere, G., Hu, X., Koshland, D., and Tapia, H. (2018). Synergy between the small intrinsically disordered protein Hsp12 and trehalose sustain viability after severe desiccation. eLife 7, 1-20. doi: 10.7554/eLife.38337

King, A. M., and MacRae, T. H. (2012). The small heat shock protein p26 aids development of encysting Artemia embryos, prevents spontaneous diapause termination and protects against stress. PLoS One 7:e0043723. doi: 10.1371/ journal.pone.0043723

King, A. M., Toxopeus, J., and Macrae, T. H. (2013). Functional differentiation of small heat shock proteins in diapause-destined Artemia embryos. FEBS J. 280, 4761-4772. doi: 10.1111/febs.12442

King, A. M., Toxopeus, J., and MacRae, T. H. (2014). Artemin, a diapause-specific chaperone, contributes to the stress tolerance of Artemia franciscana cysts and influences their release from females. J. Exp. Biol. 217, 1719-1724. doi: 10.1242/ jeb. 100081

Kormish, J. D., and McGhee, J. D. (2005). The C. elegans lethal gut-obstructed gob-1 gene is trehalose-6-phosphate phosphatase. Dev. Biol. 287, 35-47. doi: 10.1016/j.ydbio.2005.08.027

Koster, K. L., Webb, M. S., Bryant, G., and Lynch, D. V. (1994). Interactions between soluble sugars and POPC (1-palmitoyl-2-oleoylphosphatidylcholine) during dehydration: vitrification of sugars alters the phase behavior of the phospholipid. Biochim. Biophys. Acta 1193, 143-150. doi: 10.1016/00052736(94)90343-3

Laksanalamai, P., and Robb, F. T. (2004). Small heat shock proteins from extremophiles: a review. Extremophiles 8, 1-11. doi: 10.1007/s00792-003-03623

Lapinski, J., and Tunnacliffe, A. (2003). Anhydrobiosis without trehalose in bdelloid rotifers. FEBS Lett. 553, 387-390. doi: 10.1016/S0014-5793(03)010627

LeBlanc, B. M., Le, M. T., Janis, B., Menze, M. A., and Hand, S. C. (2019). Structural properties and cellular expression of AfrLEA6, a group 6 late embryogenesis abundant protein from embryos of Artemia franciscana. Cell Stress Chaperones 24, 979-990. doi: 10.1007/s12192-019-01025-8

Li, D., and He, X. (2009). Desiccation induced structural alterations in a 66-amino acid fragment of an anhydrobiotic nematode late embryogenesis abundant (LEA) protein. Biomacromolecules 10, 1469-1477. doi: 10.1021/bm9002688

Li, S., Chakraborty, N., Borcar, A., Menze, M. A., Toner, M., and Hand, S. C. (2012). Late embryogenesis abundant proteins protect human hepatoma cells during acute desiccation. Proc. Natl. Acad. Sci. U.S.A. 109, 20859-20864. doi: 10.1073/pnas.1214893109

Liang, P., Amons, R., Clegg, J. S., and MacRae, T. H. (1997a). Molecular characterization of a small heat shock/ $\alpha$-crystallin protein in encysted Artemia embryos. J. Biol. Chem. 272, 19051-19058. doi: 10.1074/jbc.272.30.19051

Liang, P., Amons, R., Macrae, T. H., and Clegg, J. S. (1997b). Purification, structure and in vitro molecular-chaperone activity of Artemia p26, a small heat-shock/ $\alpha$ crystallin protein. Eur. J. Biochem. 243, 225-232. doi: 10.1111/j.1432-1033.1997. 0225a.x

Liang, P., and MacRae, T. H. (1999). The synthesis of a small heat shock/ $\alpha-$ crystallin protein in Artemia and its relationship to stress tolerance during development. Dev. Biol. 207, 445-456. doi: 10.1006/dbio.1998.9138

Lin, C., Jia, S. N., Yang, F., Jia, W. H., Yu, X. J., Yang, J. S., et al. (2016). The transcription factor $\mathrm{p} 8$ regulates autophagy during diapause embryo formation in Artemia parthenogenetica. Cell Stress Chaperones 21, 665-675. doi: 10.1007/ s12192-016-0692-6

Liu, F., Thatcher, J. D., Barral, J. M., and Epstein, H. F. (1995). Bifunctional glyoxylate cycle protein of Caenorhabditis elegans: a developmentally regulated protein of intestine and muscle. Dev. Biol. 169, 399-414. doi: 10.1006/dbio.1995. 1156

Liu, L., Li, Y., Wang, R., Yin, C., Dong, Q., Hing, H., et al. (2007). Drosophila hygrosensation requires the TRP channels water witch and nanchung. Nature 450, 294-298. doi: 10.1038/nature06223

Liu, Y., Chakrabortee, S., Li, R., Zheng, Y., and Tunnacliffe, A. (2011). Both plant and animal LEA proteins act as kinetic stabilisers of polyglutamine-dependent protein aggregation. FEBS Lett. 585, 630-634. doi: 10.1016/j.febslet.2011. 01.020

Liu, Y., Zhang, H., Han, J., Jiang, S., Geng, X., Xue, D., et al. (2019). Functional assessment of hydrophilic domains of late embryogenesis abundant proteins from distant organisms. Microb. Biotechnol. 12, 752-762. doi: 10.1111/17517915.13416
Liu, Y. L., Zhao, Y., Dai, Z. M., Chen, H. M., and Yang, W. J. (2009). Formation of diapause cyst shell in brine shrimp, Artemia parthenogenetica, and its resistance role in environmental stresses. J. Biol. Chem. 284, 16931-16938. doi: 10.1074/ jbc.M109.004051

Loomis, S. H., Madin, K. A. C., and Crowe, J. H. (1980). Anhydrobiosis in nematodes: biosynthesis of trehalose. J. Exp. Zool. 211, 311-320. doi: 10.1002/ jez.1402110308

Ma, X., Jamil, K., MacRae, T. H., Clegg, J. S., Russell, J. M., Villeneuve, T. S., et al. (2005). A small stress protein acts synergistically with trehalose to confer desiccation tolerance on mammalian cells. Cryobiology 51, 15-28. doi: 10.1016/ j.cryobiol.2005.04.007

MacRae, T. H. (2016). Stress tolerance during diapause and quiescence of the brine shrimp, Artemia. Cell Stress Chaperones 21, 9-18. doi: 10.1007/s12192-0150635-7

Madin, K. A. C., and Crowe, J. H. (1975). Anhydrobiosis in nematodes: carbohydrate and lipid metabolism during dehydration. J. Exp. Zool. 193, 335-342.

Madin, K. A. C., Loomis, S. H., and Crowe, J. H. (1985). Anhydrobiosis in nematodes: control of carbon flow through the glyoxylate cycle. J. Exp. Zool. 234, 341-350. doi: 10.1002/jez.1402340303

Marunde, M. R., Samarajeewa, D. A., Anderson, J., Li, S., Hand, S. C., and Menze, M. A. (2013). Improved tolerance to salt and water stress in Drosophila melanogaster cells conferred by late embryogenesis abundant protein. J. Insect Physiol. 59, 377-386. doi: 10.1016/j.jinsphys.2013.01.004

Mazin, P. V., Shagimardanova, E., Kozlova, O., Cherkasov, A., Sutormin, R., Stepanova, V. V., et al. (2018). Cooption of heat shock regulatory system for anhydrobiosis in the sleeping chironomid Polypedilum vanderplanki. Proc. Natl. Acad. Sci. U.S.A. 115:201719493. doi: 10.1073/pnas.1719493115

McLennan, A. G. (2009). Ametabolic embryos of Artemia franciscana accumulate DNA damage during prolonged anoxia. J. Exp. Biol. 212, 785-789. doi: 10.1242/ jeb.023663

McNuff, R. (2018). Laboratory culture of hypsibius exemplaris. Cold Spring Harb. Protoc. 2018, 867-870. doi: 10.1101/pdb.prot102319

Menze, M. A., Boswell, L., Toner, M., and Hand, S. C. (2009). Occurrence of mitochondria-targeted late embryogenesis abundant (LEA) gene in animals increases organelle resistance to water stress. J. Biol. Chem. 284, 10714-10719. doi: 10.1074/jbc.C900001200

Møbjerg, N., Halberg, K. A., Jørgensen, A., Persson, D., Bjørn, M., Ramløv, H., et al. (2011). Survival in extreme environments - on the current knowledge of adaptations in tardigrades. Acta Physiol. 202, 409-420. doi: 10.1111/j.17481716.2011.02252.x

Moore, D. S., and Hand, S. C. (2016). Cryopreservation of lipid bilayers by LEA proteins from Artemia franciscana and trehalose. Cryobiology 73, 240-247. doi: 10.1016/j.cryobiol.2016.07.003

Moore, D. S., Hansen, R., and Hand, S. C. (2016). Liposomes with diverse compositions are protected during desiccation by LEA proteins from Artemia franciscana and trehalose. Biochim. Biophys. Acta Biomembr. 1858, 104-115. doi: 10.1016/j.bbamem.2015.10.019

Morris, J. E., and Afzelius, B. A. (1967). The structure of the shell and outer membranes in encysted Artemia salina embryos during cryptobiosis and development. J. Ultrasructure Res. 20, 244-259. doi: 10.1016/S0022-5320(67) 90285-7

Nambu, Z., Tanaka, S., and Nambu, F. (2004). Influence of photoperiod and temperature on reproductive mode in the brine shrimp, Artemia franciscana. J. Exp. Zool. Part A Comp. Exp. Biol. 301, 542-546. doi: 10.1002/jez.a.80

Nambu, Z., Tanaka, S., Nambu, F., and Nakano, M. (2008). Influence of temperature and darkness on embryonic diapause termination in dormant artemia cysts that have never been desiccated. J. Exp. Zool. 309, 17-24. doi: $10.1002 /$ jez

Nance, J., and Frøkjær-Jensen, C. (2019). The caenorhabditis elegans transgenic toolbox. Genetics 212, 959-990. doi: 10.1534/genetics.119.301506

Needham, T. (1743). A letter concerning chalky tubulous con- cretions, with some microscopical observations on the farina of the red lilly, and on worms discovered in smutty corn. Phil. Trans. 42, 634-641. doi: 10.1017/ CBO9781107415324.004

Neumann, S., Reuner, A., Brummer, F., and Schill, R. O. (2009). DNA damage in storage cells of anhydrobiotic tardigrades. Comp. Biochem. Physiol. A Mol. Integr. Physiol. 153, 425-429. doi: 10.1016/j.cbpa.2009.04.611 
Neves, R. C., Hvidepil, L. K. B., Sørensen-Hygum, T. L., Stuart, R. M., and Møbjerg, N. (2020). Thermotolerance experiments on active and desiccated states of Ramazzottius varieornatus emphasize that tardigrades are sensitive to high temperatures. Sci. Rep. 10, 1-12. doi: 10.1038/s41598-01956965-Z

Olson, C. S., and Clegg, J. S. (1978). Cell division during the development of Artemia salina. Wilhelm Roux's Arch. Dev. Biol. 184, 1-13. doi: 10.1007/ BF00848665

O'Riordan, V. B., and Burnell, A. M. (1989). Intermediary metabolism in the dauer larva of the nematode Caenorhabditis elegans-1. Glycolysis, gluconeogenesis, oxidative phosphorylation and the tricarboxylic acid cycle. Comp. Biochem. Physiol. B Biochem. 92, 233-238. doi: 10.1016/0305-0491(89)90271-X

O'Riordan, V. B., and Burnell, A. M. (1990). Intermediary metabolism in the dauer larva of the nematode Caenorhabditis elegans-II. The glyoxylate cycle and fatty-acid oxidation. Comp. Biochem. Physiol. B Biochem. 95, 125-130. doi: 10.1016/0305-0491(90)90258-U

Park, S. K., Tedesco, P. M., and Johnson, T. E. (2009). Oxidative stress and longevity in Caenorhabditis elegans as mediated by SKN-1. Aging Cell 8, 258-269. doi: 10.1111/j.1474-9726.2009.00473.x

Perry, R. N. (1999). Desiccation survival of parasitic nematodes. Parasitology 119, S19-S30. doi: 10.1017/s0031182000084626

Pigon, A., and Weglarska, B. (1955). Rate of metabolism in tardigrades during active life and anabiosis. Nature 176, 121-122. doi: 10.1038/175642b0

Podrabsky, J. E., Carpenter, J. F., and Hand, S. C. (2001). Survival of water stress in annual fish embryos: dehydration avoidance and egg envelope amyloid fibers. Am. J. Physiol. Regul. Integr. Comp. Physiol. 280, 123-131. doi: 10.1152/ajpregu. 2001.280.1.r123

Qiu, Z., and MacRae, T. H. (2007). Developmentally regulated synthesis of p8, a stress-associated transcription cofactor, in diapause-destined embryos of Artemia franciscana. Cell Stress Chaperones 12, 255-264. doi: 10.1379/CSC-275. 1

Qiu, Z., and MacRae, T. H. (2008a). ArHsp21, a developmentally regulated small heat-shock protein synthesized in diapausing embryos of Artemia franciscana. Biochem. J. 411, 605-611. doi: 10.1042/BJ20071472

Qiu, Z., and MacRae, T. H. (2008b). ArHsp22, a developmentally regulated small heat shock protein produced in diapause-destined Artemia embryos, is stress inducible in adults. FEBS J. 275, 3556-3566. doi: 10.1111/j.1742-4658.2008. 06501.x

Qiu, Z., Tsoi, S. C. M., and MacRae, T. H. (2007). Gene expression in diapausedestined embryos of the crustacean, Artemia franciscana. Mech. Dev. 124, 856-867. doi: 10.1016/j.mod.2007.09.001

Rebecchi, L., Cesari, M., Altiero, T., Frigieri, A., and Guidetti, R. (2009). Survival and DNA degradation in anhydrobiotic tardigrades. J. Exp. Biol. 212, 40334039. doi: $10.1242 /$ jeb. 033266

Rebecchi, L., Guidetti, R., Borsari, S., Altiero, T., and Bertolani, R. (2006). Dynamics of long-term anhydrobiotic survival of lichen-dwelling tardigrades. Hydrobiologia 558, 23-30. doi: 10.1007/s10750-005-1415-7

Reuner, A., Hengherr, S., Mali, B., Förster, F., Arndt, D., Reinhardt, R., et al. (2010). Stress response in tardigrades: differential gene expression of molecular chaperones. Cell Stress Chaperones 15, 423-430. doi: 10.1007/s12192-009-01581

Richaud, M., Le Goff, E., Cazevielle, C., Ono, F., Mori, Y., Saini, N. L., et al. (2020). Ultrastructural analysis of the dehydrated tardigrade Hypsibius exemplaris unveils an anhydrobiotic-specific architecture. Sci. Rep. 10, 1-11. doi: 10.1038/ s41598-020-61165-1

Riddle, D. L., Swanson, M. M., and Albert, P. S. (1981). Interacting genes in nematode dauer larva formation. Nature 290, 668-671. doi: 10.1038/290668a0

Rizzo, A. M., Negroni, M., Altiero, T., Montorfano, G., Corsetto, P., Berselli, P., et al. (2010). Antioxidant defences in hydrated and desiccated states of the tardigrade Paramacrobiotus richtersi. Comp. Biochem. Physiol. B Biochem. Mol. Biol. 156, 115-121. doi: 10.1016/j.cbpb.2010.02.009

Rowarth, N. M., and MacRae, T. H. (2018a). ArHsp40 and ArHsp40-2 contribute to stress tolerance and longevity in Artemia franciscana, but only ArHsp40 influences diapause entry. J. Exp. Biol. 221:jeb189001. doi: 10.1242/jeb.189001

Rowarth, N. M., and MacRae, T. H. (2018b). Post-diapause synthesis of ArHsp402, a type 2 J-domain protein from Artemia franciscana, is developmentally regulated and induced by stress. PLoS One 13:e201477. doi: 10.1371/journal. pone.0201477
Russell, J., Vidal-Gadea, A. G., Makay, A., Lanam, C., and Pierce-Shimomura, J. T. (2014). Humidity sensation requires both mechanosensory and thermosensory pathways in Caenorhabditis elegans. Proc. Natl. Acad. Sci. U.S.A. 111, 82698274. doi: 10.1073/pnas.1322512111

Sakurai, M., Furuki, T., Akao, K. I., Tanaka, D., Nakahara, Y., Kikawada, T., et al. (2008). Vitrification is essential for anhydrobiosis in an African chironomid, Polypedilum vanderplanki. Proc. Natl. Acad. Sci. U.S.A. 105, 5093-5098. doi: 10.1073/pnas.0706197105

Sayeed, O., and Benzer, S. (1996). Behavioral genetics of thermosensation and hygrosensation. Proc. Natl. Acad. Sci. U.S.A. 93, 6079-6084.

Schill, R. O., and Fritz, G. B. (2008). Desiccation tolerance in embryonic stages of the tardigrade. J. Zool. 276, 103-107. doi: 10.1111/j.1469-7998.2008.00 474.x

Schill, R. O., Steinbruck, G. H. B., and Kohler, H. R. (2004). Stress gene (hsp70) sequences and quantitative expression in Milnesium tardigradum (Tardigrada) during active and cryptobiotic stages. J. Exp. Biol. 207, 1607-1613. doi: 10.1242/ jeb.00935

Schokraie, E., Hotz-Wagenblatt, A., Warnken, U., Frohme, M., Dandekar, T., Schill, R. O., et al. (2011). Investigating heat shock proteins of tardigrades in active versus anhydrobiotic state using shotgun proteomics. J. Zool. Syst. Evol. Res. 49, 111-119. doi: 10.1111/j.1439-0469.2010.00608.x

Schokraie, E., Hotz-Wagenblatt, A., Warnken, U., Mali, B., Frohme, M., Förster, F., et al. (2010). Proteomic analysis of tardigrades: towards a better understanding of molecular mechanisms by anhydrobiotic organisms. PLoS One 5:e0009502. doi: 10.1371/journal.pone.0009502

Seki, K., and Toyoshima, M. (1998). Preserving tardigrades under pressure. Nature 395, 853-854. doi: 10.1038/27576

Seo, Y., Kingsley, S., Walker, G., Mondoux, M. A., and Tissenbaum, H. A. (2018). Metabolic shift from glycogen to trehalose promotes lifespan and healthspan in Caenorhabditis elegans. Proc. Natl. Acad. Sci. U.S.A. 115, E2791-E2800. doi: 10.1073/pnas.1714178115

Shahangian, S. S., Rasti, B., Sajedi, R. H., Khodarahmi, R., Taghdir, M., and Ranjbar, B. (2011). Artemin as an efficient molecular chaperone. Protein J. 30, 549-557. doi: 10.1007/s10930-011-9359-4

Shannon, A. J., Browne, J. A., Boyd, J., Fitzpatrick, D. A., and Burnell, A. M. (2005). The anhydrobiotic potential and molecular phylogenetics of species and strains of Panagrolaimus (Nematoda, Panagrolaimidae). J. Exp. Biol. 208, 2433-2445. doi: 10.1242/jeb.01629

Sharon, M. A., Kozarova, A., Clegg, J. S., Vacratsis, P. O., and Warner, A. H. (2009). Characterization of a group 1 late embryogenesis abundant protein in encysted embryos of the brine shrimp Artemia franciscana. Biochem. Cell Biol. 87, 415-430. doi: 10.1139/O09-001

Shimizu, T., Kanamori, Y., Furuki, T., Kikawada, T., Okuda, T., Takahashi, T., et al. (2010). Desiccation-induced structuralization and glass formation of group 3 late embryogenesis abundant protein model peptides. Biochemistry 49, 1093-1104. doi: 10.1021/bi901745f

Sliggers, B., and Engelmann, M. (2015). Johannes Albertus Schlosser, the first author describing Artemia salina(L.) (Branchiopoda: Anostraca): a biographical sketch. J. Crustac. Biol. 35, 571-575. doi: 10.1163/1937240X-000 02352

Sorgeloos, P. (1973). First report on the triggering effect of light on the hatching mechanism of Artemia salina dry cysts. Mar. Biol. 22, 75-76. doi: 10.1007/ BF00388912

Sorgeloos, P. (1980). "The use of the brine shrimp Artemia in aquaculture," in The Brine Shrimp Artemia, eds G. Persoone, P. Sorgeloos, O. Roels, and E. Jaspers (Wetteren: Universa Press), 25-46.

Sorgeloos, P., Bossuyt, E., Laviña, E., Baeza-Mesa, M., and Persoone, G. (1977). Decapsulation of Artemia cysts: a simple technique for the improvement of the use of brine shrimp in aquaculture. Aquaculture 12, 311-315. doi: 10.1016/ 0044-8486(77)90209-5

Spallanzani, L., and Dalyell, J. G. (1803). Tracts on the Nature of Animals and Vegetables. Edinburgh: William Creech and Archibald Constable, doi: 10.5962/ bhl.title. 118582

Sun, W. Q., and Leopold, A. C. (1997). Cytoplasmic vitrification and survival of anhydrobiotic organisms. Comp. Biochem. Physiol. A Physiol. 117, 327-333. doi: 10.1016/S0300-9629(96)00271-X

Sun, Y., Bojikova-Fournier, S., and MacRae, T. H. (2006). Structural and functional roles for $\beta$-strand 7 in the $\alpha$-crystallin domain of $\mathrm{p} 26$, a polydisperse small 
heat shock protein from Artemia franciscana. FEBS J. 273, 1020-1034. doi: 10.1111/j.1742-4658.2006.05129.x

Sun, Y., Mansour, M., Crack, J. A., Gass, G. L., and MacRae, T. H. (2004). Oligomerization, chaperone activity, and nuclear localization of p26, a small heat shock protein from Artemia franciscana. J. Biol. Chem. 279, 39999-40006. doi: $10.1074 /$ jbc.M406999200

Tan, J., and MacRae, T. H. (2018). Stress tolerance in diapausing embryos of Artemia franciscana is dependent on heat shock factor 1 (Hsf1). PLoS One 13:e0200153. doi: 10.1371/journal.pone. 0200153

Tan, J., and MacRae, T. H. (2019). The synthesis of diapause-specific molecular chaperones in embryos of Artemia franciscana is determined by the quantity and location of heat shock factor 1 (Hsf1). Cell Stress Chaperones 24, 385-392. doi: 10.1007/s12192-019-00971-7

Tanaka, S., Tanaka, J., Miwa, Y., Horikawa, D. D., Katayama, T., Arakawa, K., et al. (2015). Novel mitochondria-targeted heat-soluble proteins identified in the anhydrobiotic tardigrade improve osmotic tolerance of human cells. PLoS One 10:e0118272. doi: 10.1371/journal.pone.0118272

Tanguay, J. A., Reyes, R. C., and Clegg, J. S. (2004). Habitat diversity and adaptation to environmental stress in encysted embryos of the crustacean Artemia. J. Biosci 29, 489-501.

Tenlen, J. R., McCaskill, S., and Goldstein, B. (2013). RNA interference can be used to disrupt gene function in tardigrades. Dev. Genes Evol. 223, 171-181. doi: $10.1007 / \mathrm{s} 00427-012-0432-6$

Tolleter, D., Jaquinod, M., Mangavel, C., Passirani, C., Saulnier, P., Manon, S., et al. (2007). Structure and function of a mitochondrial late embryogenesis abundant protein are revealed by desiccation. Plant Cell 19, 1580-1589. doi: 10.1105/tpc.107.050104

Toxopeus, J., Warner, A. H., and MacRae, T. H. (2014). Group 1 LEA proteins contribute to the desiccation and freeze tolerance of Artemia franciscana embryos during diapause. Cell Stress Chaperones 19, 939-948. doi: 10.1007/ s12192-014-0518-3

Tsujimoto, M., Imura, S., and Kanda, H. (2016). Recovery and reproduction of an Antarctic tardigrade retrieved from a moss sample frozen for over 30 years. Cryobiology 72, 78-81. doi: 10.1016/j.cryobiol.2015.12.003

Tunnacliffe, A., Lapinski, J., and McGee, B. (2005). A putative LEA protein, but no trehalose, is present in anhydrobiotic bdelloid rotifers. Hydrobiologia 546, 315-321. doi: 10.1007/s10750-005-4239-6

Tunnacliffe, A., and Wise, M. J. (2007). The continuing conundrum of the LEA proteins. Naturwissenschaften 94, 791-812. doi: 10.1007/s00114-007-0254-y

Tyson, T., O'Mahony Zamora, G., Wong, S., Skelton, M., Daly, B., Jones, J. T., et al. (2012). A molecular analysis of desiccation tolerance mechanisms in the anhydrobiotic nematode Panagrolaimus superbus using expressed sequenced tags. BMC Res. Notes 5:68. doi: 10.1186/1756-0500-5-68

Vihervaara, A., Duarte, F. M., and Lis, J. T. (2018). Molecular mechanisms driving transcriptional stress responses. Nat. Rev. Genet. 19, 385-397. doi: 10.1038/ s41576-018-0001-6

Wang, C., Grohme, M. A., Mali, B., Schil, R. O., and Frohme, M. (2014). Towards decrypting cryptobiosis - analyzing anhydrobiosis in the tardigrade Milnesium tardigradum using transcriptome sequencing. PLoS One 9:e0092663. doi: 10. 1371/journal.pone.0092663

Warner, A. H., Chakrabortee, S., Tunnacliffe, A., and Clegg, J. S. (2012). Complexity of the heat-soluble LEA proteome in Artemia species. Comp. Biochem. Physiol. D Genomics Proteom. 7, 260-267. doi: 10.1016/j.cbd.2012.04. 002

Warner, A. H., Miroshnychenko, O., Kozarova, A., Vacratsis, P. O., MacRae, T. H., Kim, J., et al. (2010). Evidence for multiple group 1 late embryogenesis abundant proteins in encysted embryos of Artemia and their organelles. J. Biochem. 148, 581-592. doi: 10.1093/jb/mvq091

Westh, P., and Ramløv, H. (1991). Trehalose accumulation in the tardigrade Adorybiotus coronifer during anhydrobiosis. J. Exp. Zool. 258, 303-311. doi: 10.1002/jez.1402580305

Wharton, D. A. (1996). Water loss and morphological changes during desiccation of the anhydrobiotic nematode Ditylenchus dipsaci. J. Exp. Biol. 199, 10851093.

Wharton, D. A. (2011). Anhydrobiosis: the model worm as a model? Curr. Biol. 21, R578-R579. doi: 10.1016/j.cub.2011.06.040

Williams, R. J., and Leopold, A. C. (1989). The glassy state in corn embryos. Plant Physiol. 89, 977-981. doi: 10.1104/pp.89.3.977

Willsie, J. K., and Clegg, J. S. (2001). Nuclear p26, a small heat shock/a-crystallin protein, and its relationship to stress resistance in Artemia franciscana embryos. J. Exp. Biol. 204, 2339-2350.

Willsie, J. K., and Clegg, J. S. (2002). Small heat shock protein p26 associates with nuclear lamins and HSP70 in nuclei and nuclear matrix fractions from stressed cells. J. Cell. Biochem. 84, 601-614. doi: 10.1002/jcb. 10040

Wise, M. J., and Tunnacliffe, A. (2004). POPP the question: what do LEA proteins do? Trends Plant Sci. 9, 13-17. doi: 10.1016/j.tplants.2003.10.012

Wolkers, W. F., McCready, S., Brandt, W. F., Lindsey, G. G., and Hoekstra, F. A. (2001). Isolation and characterization of a D-7 LEA protein from pollen that stabilizes glasses in vitro. Biochim. Biophys. Acta Protein Struct. Mol. Enzymol. 1544, 196-206. doi: 10.1016/S0167-4838(00)00220-X

Wright, J. C. (1989). Desiccation tolerance and water-retentive mechanisms in tardigrades. J. Exp. Biol. 142, 267-292.

Wu, G., Zhang, H., Sun, J., Liu, F., Ge, X., Chen, W. H., et al. (2011). Diverse LEA (late embryogenesis abundant) and LEA-like genes and their responses to hypersaline stress in post-diapause embryonic development of Artemia franciscana. Comp. Biochem. Physiol. B Biochem. Mol. Biol. 160, 32-39. doi: 10.1016/j.cbpb.2011.05.005

Yamaguchi, A., Tanaka, S., Yamaguchi, S., Kuwahara, H., Takamura, C., ImajohOhmi, S., et al. (2012). Two novel heat-soluble protein families abundantly expressed in an anhydrobiotic tardigrade. PLoS One 7:e0044209. doi: 10.1371/ journal.pone.0044209

Yoshida, Y., Koutsovoulos, G., Laetsch, D. R., Stevens, L., Kumar, S., Horikawa, D. D., et al. (2017). Comparative genomics of the tardigrades Hypsibius dujardini and Ramazzottius varieornatus. PLoS Biol. 15:e2002266. doi: 10.1371/ journal.pbio.2002266

Yuen, F., Watson, M., Barker, R., Grillo, I., Heenan, R. K., Tunnacliffe, A., et al. (2019). Preferential adsorption to air-water interfaces: a novel cryoprotective mechanism for LEA proteins. Biochem. J. 476, 1121-1135. doi: 10.1042/ BCJ20180901

Conflict of Interest: The authors declare that the research was conducted in the absence of any commercial or financial relationships that could be construed as a potential conflict of interest.

Copyright (®) 2020 Hibshman, Clegg and Goldstein. This is an open-access article distributed under the terms of the Creative Commons Attribution License (CC BY). The use, distribution or reproduction in other forums is permitted, provided the original author(s) and the copyright owner(s) are credited and that the original publication in this journal is cited, in accordance with accepted academic practice. No use, distribution or reproduction is permitted which does not comply with these terms. 